\title{
Resolving Metabolic Heterogeneity in Experimental Models of the Tumor Microenvironment from a Stable Isotope Resolved Metabolomics Perspective
}

\author{
Teresa W. -M. Fan ${ }^{1,2, *}$, Richard M. Higashi ${ }^{1,2}$, Yelena Chernayavskaya ${ }^{1}$ and \\ Andrew N. Lane $1,2, *$ iD \\ 1 Center for Environmental and Systems Biochemistry, Lexington, KY 40536, USA; \\ rick.higashi@uky.edu (R.M.H.); ych354@uky.edu (Y.C.) \\ 2 Department of Toxicology and Cancer Biology, University of Kentucky, Lexington, KY 40536, USA \\ * Correspondence: Teresa.fan@uky.edu (T.W.-M.F.); Andrew.lane@uky.edu (A.N.L.)
}

\begin{abstract}
The tumor microenvironment (TME) comprises complex interactions of multiple cell types that determines cell behavior and metabolism such as nutrient competition and immune suppression. We discuss the various types of heterogeneity that exist in solid tumors, and the complications this invokes for studies of TME. As human subjects and in vivo model systems are complex and difficult to manipulate, simpler 3D model systems that are compatible with flexible experimental control are necessary for studying metabolic regulation in TME. Stable Isotope Resolved Metabolomics (SIRM) is a valuable tool for tracing metabolic networks in complex systems, but at present does not directly address heterogeneous metabolism at the individual cell level. We compare the advantages and disadvantages of different model systems for SIRM experiments, with a focus on lung cancer cells, their interactions with macrophages and T cells, and their response to modulators in the immune microenvironment. We describe the experimental set up, illustrate results from 3D cultures and co-cultures of lung cancer cells with human macrophages, and outline strategies to address the heterogeneous TME.
\end{abstract}

Keywords: tumor microenvironment; 3D cultures; tissue slices; stable isotope resolved metabolomics

\section{Introduction}

\subsection{Heterogeneity in the Tumor Microenvironment (TME)}

Most tissues and solid tumors are highly heterogeneous at the molecular, cellular, and regional levels, as well as across entire organ. Thus, heterogeneity is the rule rather than the exception. Table 1 summarizes some of the known types of heterogeneity in solid tumors [1-13]. 
Table 1. Tumor tissue heterogeneity. Scale refers to the size of the unit, from individual cells (local) to groups of cells or tissue (regional) to global (organism).

\begin{tabular}{|c|c|c|c|}
\hline Scale & Heterogeneity & Examples & Refs. \\
\hline Global & Cell types & $\begin{array}{l}\text { Normal and transformed epithelia, fibroblasts, } \\
\text { endothelia, and resident and infiltrating } \\
\text { immune cells. }\end{array}$ & Figure $1 ;[14,15]$ \\
\hline Regional & Cancer cellularity & $<10->90 \%$ of total cells & {$[16,17]$} \\
\hline Regional & vascularity & $\begin{array}{l}\text { Restricted flow -> local hypoxia, nutrient } \\
\text { deprivation, waste buildup; gradients in IF } \\
\text { impacts on cell gene expression. }\end{array}$ & [18-21] \\
\hline Regional/local & $\begin{array}{l}\text { Disrupted ECM and } \\
\text { tissue organization }\end{array}$ & $\begin{array}{l}\text { Altered cell interactions: impacts on cell gene } \\
\text { expression. }\end{array}$ & {$[21,22]$} \\
\hline Regional/local & Cell-cell interactions & $\begin{array}{l}\text { Direct cell contacts versus interaction via } \\
\text { diffusible molecules: altered behavior of T cells, } \\
\text { macrophage polarization (TAMs), and } \\
\text { fibroblast activity (CAFs). }\end{array}$ & {$[23,24]$} \\
\hline Global & Cell-cell interactions & $\begin{array}{l}\text { Tissue polarity impacts cell function by } \\
\text { position - cells or groups of cells have different } \\
\text { metabolic activities according to position, and } \\
\text { different cell types have different metabolic } \\
\text { activities. The "intrinsic" metabolic phenotypes } \\
\text { of cells are greatly influenced by interactions } \\
\text { within heterogeneous tissues. }\end{array}$ & {$[25,26]$} \\
\hline Regional/local & Cell distribution & $\begin{array}{c}\text { Cell distribution is highly heterogeneous } \\
\text { (clumps and voids-regional versus cellular } \\
\text { heterogeneity). }\end{array}$ & Figure $1 ;[27,28]$ \\
\hline Local & Cells & $\begin{array}{l}\text { Cells within tumors may have different } \\
\text { expression patterns as well as different genome } \\
\text { alterations. Expression patterns may vary in } \\
\text { part from environmental influences on } \\
\text { epigenetics (chromatin structure). }\end{array}$ & {$[24,29,30]$} \\
\hline Regional & Necrosis & $\begin{array}{l}\text { Heterogeneous because of variable necrosis in } \\
\text { different regions of the tumor }\end{array}$ & [31] \\
\hline Organ & $\begin{array}{l}\text { Tissue-dependent } \\
\text { tumors; subtypes }\end{array}$ & $\begin{array}{c}\text { Tumors of the same tissue origin are } \\
\text { heterogeneous-subtypes (adeno versus } \\
\text { squamous versus NET etc.) that are } \\
\text { characterized by different functional properties. } \\
\text { Some subtypes can interconvert (cf. lung } \\
\text { adenosquamous phenotype). Cancer cells can } \\
\text { also undergo EMT. Cells may de-differentiate } \\
\text { or even trans differentiate. }\end{array}$ & [32-38] \\
\hline Local & Cell structure & Cells are compartmented and heterogeneous. & [39] \\
\hline
\end{tabular}

Heterogeneity imposes many problems for detailed analysis of the molecular and cellular behavior of solid tumors, partly because of technical limitations. This is critical to the fundamental understanding of tumor biology and the design of therapeutic strategies. Nevertheless, considerable progress is being made via single cell analyses of genome, transcriptome [13,21,22,40-49], proteome [50-52], and metabolome [8,52-57]. Although spatially resolved single cell metabolism has long been studied by live cell microscopy, the number of metabolites that can be detected and quantified is very limited [58-61]. The more recent single cell metabolomics development can capture more metabolites, but it is limited to those at high abundance while there are important issues on quantitation and reproducibility yet to be resolved [55]. Moreover, a major issue in single-cell analysis is how to preserve biochemical integrity, cell-cell interactions, and spatial configuration during measurement. These aspects of cell and tissue architecture are essential to our understanding of cell behavior in the heterogeneous environment. For example, cells behavior differs according to direct homo and heterotopic contacts versus interactions via diffusing molecules or vesicles $[62,63]$.

Figure 1A shows an example of heterogeneous cellular distribution in non-small cell lung cancer (NSCLC) tissues visualized with hematoxylin and eosin (H\&E) stain. Different cell types including cancer cell and immune cells and their distributions are assessed morphologically. With the recent development of Digital Spatial Profiling (DSP), multiplexing bar-coded antibodies or oligonucleotide 
probes each for a different protein or mRNA target is employed to obtain the spatial distribution of multiple targets in tissues at single cell type resolution [64-66] (e.g., Figure 1B). What is clear from Figure 1 is the highly heterogeneous distribution of different cell types. As cancer cells are found in different microenvironments, their biochemical properties are likely to vary across the tissue field. Indeed, scRNAseq profiles reveal heterogeneity in mRNA expression not only among different cell types but also within each cell type [46,67-69]. However, mRNA levels do not always translate to protein levels and metabolic functions [45,70-73], which therefore needs verification. Furthermore, the TME is strongly influenced by the vasculature, which can limit the blood flow and thus $\mathrm{O}_{2} /$ nutrient supply as well as waste product removal $[18,74,75]$, and by the extracellular matrix (ECM) deposited by cancer-associated fibroblasts (CAF) [67,76-78]. Together, these factors not only dictate the availability of nutrients and competition among cell types for these nutrients but can also alter the microenvironment to favor cancer cell growth [79].
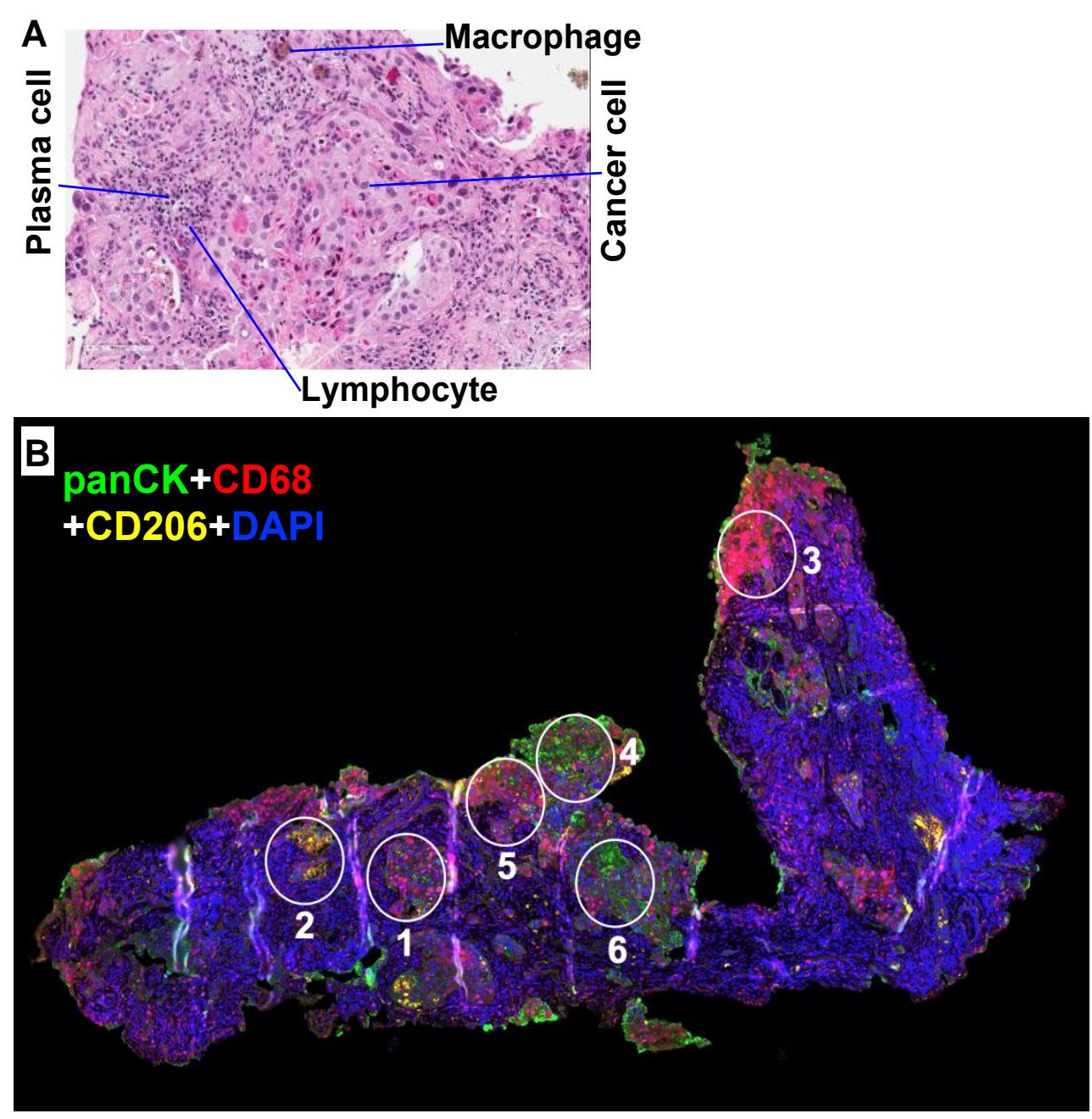

Figure 1. Heterogenous cellularity in organotypic tissue cultures (OTC) of non-small cell lung cancer (NSCLC) patient tumor tissues. The freshly resected NSCLC patient tumor tissues were thinly sliced and incubated in Dulbecco's Modified Eagle's Medium (DMEM) medium as OTC for $24 \mathrm{~h}$ at $37^{\circ} \mathrm{C} / 5 \%$ $\mathrm{CO}_{2}$ before fixing in $4 \%$ buffered formalin, embedded in paraffin block, and sectioned into $4 \mu \mathrm{m}$ slices for H\&E staining in (A) and IF staining for cancer cells (panCytokeratin or panCK), CD8 (cytotoxic T cells), and CD68 (M $\phi)$ in (B). Highly heterogeneous distribution of cancer cells and various immune cell types is evident. White circles (200 $\mu$ m diameter) in (B) defined the regions of interest (ROI) for the ROI-specific analysis (DSP) of 58 different protein markers that reflect immune functions. Each ROI was enriched in CD8 T cells (3), M $\phi(2)$, and cancer cells $(4,6)$, or contained a mixture the three cell types $(\mathbf{1}, \mathbf{5})$. 


\subsection{Stable Isotope Resolved Metabolomics (SIRM)}

Metabolic profiling of tissues and biofluids including blood plasma [80-83], urine [84-86], and cerebrospinal fluid (CSF) [86-89] using NMR and MS in the past decade has been shown to be very valuable for reporting disease states and drug responses. This is due to metabolic reprogramming in response to disease development, particularly for cancer. In fact, metabolic reprogramming is a hallmark of human cancer that drives cancer development and progression [28]. However, profiles of steady-state metabolite levels determined by NMR and/or MS cannot resolve intersecting and compartmentalized metabolic networks, as given metabolite levels are influenced by multiple factors such as rates of synthesis and/or degradation, multiple inputs/outputs, and exchanges across compartments. However, the complexity of metabolic networks can be resolved with the use of stable isotope tracers coupled with metabolomic analysis, which we termed Stable Isotope-Resolved Metabolomics or SIRM [90]. SIRM enables individual atoms in tracers such as ${ }^{13} \mathrm{C}_{6}$-glucose to be tracked through metabolic transformations so that intersecting and compartmentalized metabolic networks can be rigorously reconstructed without the ambiguities known to metabolite profiling-based pathway analysis described above. Stable isotopes especially ${ }^{13} \mathrm{C},{ }^{15} \mathrm{~N}$, and ${ }^{2} \mathrm{H}(\mathrm{D})$ are fully biologically compatible and isotopically enriched substrates can be administered with no or minimal biological effects. Stable isotope tracing of metabolic pathways has been demonstrated in a wide variety of biological systems [32,91-97] for the reconstruction of metabolic networks [98-100] and also, in some cases, mapping of metabolic flux $[77,90,91,101-106]$.

Currently, single tracers predominate in SIRM studies. Despite the technical challenges, there are substantial advantages in developing multiplexed SIRM (mSIRM) approaches where multiple precursors containing different tracer atoms such as ${ }^{13} \mathrm{C},{ }^{15} \mathrm{~N}$, and $\mathrm{D}$ are used together. These include large expansion of metabolic network coverage without interferences from sample batch variations while greatly reducing sample requirement; the latter is crucial to studies with very limited patient-derived (PD) materials such as PD organotypic tissue culture (OTC) or organoid (PDO) studies. We have begun such development, as described in Fan et al. [107].

\section{Advantages and Disadvantages of Different Model Systems}

There are many model systems available for studying basic biological mechanisms and preclinical assessment of drug efficacy; each has its own advantages and disadvantages and thus should be tailored to the specific problem [108].

\section{1. $2 D$ Cell Models}

Two-dimensional cell cultures are widely used because of their relative simplicity, manipulability, and interpretability, and they allow for maximal flexibility in experimental control. While these models are fully compatible with manipulations of nutrient supply, genetic status, and tracer applications, they lack cell-cell interactions and 3D architectures. They have been valuable for both mechanistic and translational studies such as drug screening, with the caveat that these models do not always translate well to what occurs in vivo or clinically [109-112].

\subsection{Xenograft and PDX Mouse Models}

Mouse models with xenograft of established cancer cells or PD tissues (PDX) provide a more realistic TME with regard to 3D architectures and cell-cell interactions. However, these models cannot be used for studying immune-tumor cell interactions due to the use of immune compromised mice. Neither can they recapitulate proper patient tumor-stromal cell interactions, as xenograft models lack patient stromal cells to begin with and PDX models lose them after 2-3 generations [107,108]. Moreover, these models have no appropriate control tissue, limitations on experimental control, and complications in interpretability due to inter-organ interactions. Nevertheless, some PDX models have 
been shown to provide valuable preclinical information, such as mechanism of drug resistance [113] or responses [114,115].

\subsection{D Spheroids and Organoids}

An increasingly popular model is 3D cell culture that retains 3D architecture, cell-cell interactions and experimental control without the complexity of inter-organ interactions present in a whole organism. Three-dimensional cultures were first described by Bissel, who noted that breast cancer cells spontaneously formed acinar structures when grown on a supporting matrix [116-118]. Since then, 3D cultures and organoids have been developed for a wide range of cell types $[49,108,111,112$, 119-125]. There are many types of support matrices now available, from the widely used Matrigel (a mouse sarcoma cell extracellular matrix) to other organic polymer supports such as alginates and hydrogels [126-134]. Three-dimensional cultures can also be induced without matrix support by concentrating "magnetized" cells via introduction of nano magnetic beads under a magnetic field [121,135]. Such close cellular contact allows the formation of cell-cell junctions and extracellular matrix (ECM) [109]. Indeed, concentration of cells by centrifugation can be sufficient to induce 3D structure formation on low adherence plates [136,137] or in scaffold-free hanging droplets [138,139]. It is practical to build complex 3D structures comprising multiple cell types as co-cultures either with established cell lines (spheroids) or PD cells (PDO) that correspond more closely to the organ or tumor tissues of interest. The PDO models [49] can show macroscopic functional responses [119,120,140] markedly different from those of the 2D counterparts and closer to the patient responses $[121,133,134]$ due to their ability to emulate the 3D architectures and cell-cell interactions in patient's TME.

Although genomics [141-148] and proteomics [149,150] approaches have been widely applied to studying spheroids and organoids, there have been comparatively few studies of metabolism in these models $[35,108,124,151-164]$ and very few stable isotope tracers-based studies $[35,121,124,162]$. From the perspective of SIRM, not all 3D matrices are equal. First, Matrigel, a commonly used matrix, is an ECM derived from mouse sarcoma and is essentially an undefined medium that can vary in composition from batch to batch, leading to variable metabolic responses. Second, exchanging the growth medium in the matrix to the treatment medium is not trivial. Third, the matrix is difficult to remove fully from the embedded spheroids or organoids for harvesting, and the process is slow compared to the metabolic time scale. This can lead to undesirable changes in metabolite levels and difficulty in normalizing metabolite levels. For SIRM studies, fractional enrichments in the labeled metabolites are not influenced by the contamination of residual matrix, as they are internally normalized, but the slow speed of metabolic quenching remains a confounding factor for the biological interpretation.

An alternative to Matrigel is one of the many synthetic polymer supports, which are defined in composition and are batchwise reproducible, thereby eliminating batch artifacts and influence over protein-based normalization of metabolite content. However, the problem of medium exchange remains. It is also practical to use matrix-free magnetic-bead-based 3D culture method for metabolic studies [121]. In some systems, spheroids or organoids form without added matrix support, as the cells generate their own ECM $[106,165,166]$. In the latter two cases, control of the medium compositions and metabolic quenching will be straightforward, as the case for 2D cell culture studies.

Although spheroid or organoid assembly can emulate cell-cell interactions analogous to those found in tissues, cells in the assembly can assume different phenotypes depending on the assembly size and the nature of the matrix, with cells on the periphery showing different properties from those in the core $[121,149]$. To emulate the cellular heterogeneity of tissues, 3D co-cultures can be implemented, e.g., using mixtures of cancer cells plus immune cells, fibroblasts or endothelial cells [49,132]. The added complexity however makes it difficult to delineate the metabolic activity of each cell type, unless single cell analysis is carried out in situ. For metabolomic analysis, this remains challenging because of the low abundance of most metabolites in each cell and the difficulty of maintaining biochemical integrity and minimizing metabolite diffusion during cell isolation or in situ analysis [55]. For example, 
a metabolite present at $1 \mu \mathrm{M}$ in a cell of $1 \mathrm{pL}$ volume is only one attomole of material, which while achievable [167] is challenging to quantify even by the best mass spectrometers under ideal conditions, and is well beyond the capabilities of NMR [168] even with hyperpolarization [169]. To the best of our knowledge, single cell tracer studies have not been reported, presumably due to detectability issue. As isotopic enrichment increases the number of labeled species per metabolite to analyze, the detection sensitivity for each metabolite decreases. For example, with [U- $\left.{ }^{13} \mathrm{C}\right]$-glucose as the tracer, glutamate signal can be split into up to six different MS peaks each representing a ${ }^{13} \mathrm{C}$ isotopologue species.

Before single cell SIRM is practically attainable, several complementary approaches can be employed to help resolve heterologous metabolic contribution from each cell type and metabolic interactions between cell types in 3D co-cultures or tissues. Such approaches are generally applicable without the severe limitation on the coverage of metabolic pathways afforded by single cell metabolomics. For example, if the influence of cancer cells on macrophages (M $\phi)$, fibroblasts or T cells (and vice versa) were to be studied, one can first obtain under identical culture conditions metabolomic and RNAseq data from the pure spheroids of each cell type for comparison with the data acquired from the spheroid of mixed cell types at different cancer to stromal cell ratios. The mixed spheroids can also be subjected to microscopy including DSP for cell type-specific distribution of key molecular markers (proteins and mRNA) for phenotypes (e.g., apoptosis, proliferation) and metabolic pathways that are shown to be impacted from the bulk SIRM and RNAseq data. The cell-type-specific metabolic markers will help delineate each cell type's contribution to the altered metabolic activity mapped by the bulk SIRM analysis. For example, elevated expression of glycolytic enzymes in M $\phi$ but not in cancer cells in the co-culture point to macrophages' contribution to enhanced glycolysis informed by the bulk SIRM data. Consequently, the impact of cancer cells on M $\phi$ metabolism can be deduced by comparing $\mathrm{M} \phi$ metabolism in pure versus mixed 3D cultures.

To investigate the influence of diffusible substrates on target cell metabolism, one can treat, for example Mф spheroids with cancer cell conditioned media (CM) and perform SIRM analysis for altered metabolic pathways. Alternatively, one can perform SIRM study on spheroids of each cell type separated by a membrane, which permits diffusion of small molecules but prevents heterologous cell-cell contact. Each spheroid culture can then be analyzed free of the other cell types. By comparing SIRM data thus obtained with those acquired from mixed co-cultures described above, one can resolve the influence of diffusible substrates from that of cell-cell contract on metabolic interactions between cell types.

We have begun to develop the above described approaches to investigate metabolic interactions between human lung cancer cells and M $\phi$ in spheroid co-cultures. We have also introduced mSIRM [97, $107,121,170]$ in our studies to maximize information retrieval from limited samples and to minimize batch artifacts. The following describes some preliminary findings that illustrate the value of these approaches.

\section{Cancer Cell Conditioned Medium Has a Profound Effect on Human $\mathrm{M} \phi$ Metabolism and Effector Release}

To determine whether diffusible compounds excreted from cancer cells impact human M $\phi$ metabolism in response to polarization and an immune modulator $\beta$-glucan formulated as whole glucan particulates (WGP) we incubated M $\phi$ in CM from A549 cells. WGP is a yeast-derived D-glucose polymer in linear $\beta-1,3$ linkages, which we have shown previously to repolarize mouse $\mathrm{M} \phi$ in $2 \mathrm{D}$ culture from the anti-inflammatory (M2) to the pro-inflammatory (M1) phenotypes while inducing M1-like metabolic responses [171]. The effect of polarization and WGP's effect on human M $\phi$ metabolism has not been studied, to the best of our knowledge.

Using ${ }^{13} \mathrm{C}_{6}$-glucose $\left({ }^{13} \mathrm{C}_{6}\right.$-Glc) as a tracer, we performed a SIRM experiment on human M $\phi$ differentiated for 6 days in DMEM medium containing 10\% FBS, 0.2\% glucose (Glc), and $50 \mathrm{ng} / \mathrm{mL}$ CSF1 (M0 medium) from a volunteer's (UK96) peripheral blood monocytes (PBMC). On the $5^{\text {th }}$ day of differentiation, magnetic nanoparticles (Nanoshuttle, N3D) were loaded into the cells overnight, 
followed by reseeding of cells and spheroid formation under a strong magnetic field [121]. The spheroids were then incubated in M0 medium or polarized in M0 medium plus $100 \mathrm{ng} / \mathrm{mL}$ LPS $+20 \mathrm{ng} / \mathrm{mL}$ IFN $\gamma$ to M1- or $20 \mathrm{ng} / \mathrm{mL}$ each IL4 + IL13 to M2-type M $\phi$ for three days, followed by one day of culturing in M0 medium for the M0-, M1-, and M2-M $\phi$ and in M0 medium plus $0.1 \mathrm{mg} / \mathrm{mL}$ WGP for the M2+WGP-M $\phi$ in the presence of ${ }^{13} \mathrm{C}_{6}$-Glc. The same polarization/ ${ }^{13} \mathrm{C}_{6}$-Glc experiment was performed in parallel with the addition of $\mathrm{A} 549 \mathrm{CM}$ at 1:1 ratio to the polarization media. The CM medium was prepared by culturing A549 cells in M0 medium (with $0.1 \%$ Glc) for $24 \mathrm{~h}$ (1.16 million cells per $10 \mathrm{~cm}$ plate) and passing the medium through a $0.22 \mu \mathrm{M}$ filter before use. The polar metabolites were extracted from cells and culture media respectively with 70\% cold ethanol and $80 \%$ cold acetone. Due to the limited number of PBMC available from the volunteer, 200,000 cells were seeded each into two wells of a 96-well plate per treatment $(n=2)$, but the two replicate cell extracts were combined for the analysis by IC-UHR-FTMS, while the medium extracts for each well were analyzed separately by ${ }^{1} \mathrm{H}$ NMR as described previously [121].

Figure 2A shows the effect of the four treatments \pm A549 CM on the uptake of nutrients and the release of metabolites into the medium along with the changes of related intracellular metabolites. In the absence of $\mathrm{CM}(\mathrm{Ctl})$, the uptake of ${ }^{13} \mathrm{C}_{6}$-Glc (a) was somewhat enhanced in M1- ( $\square$ ) and $\mathrm{M} 2+\mathrm{WGP}-\mathrm{M} \phi(\square)$ compared with M2-M $\phi(\square)$, which led to increased buildup of intracellular ${ }^{13} \mathrm{C}_{6}$-fructose-1,6-bisphosphate (F1,6BP, e) but not the release of ${ }^{13} \mathrm{C}$-lactate (Lac, a) into the medium. The latter reflected little changes in the glycolytic capacity under different polarization treatments. We also saw enhanced buildup of ${ }^{13} \mathrm{C}_{3}$-F1,6BP in M1-M $\phi$ and $\mathrm{M} 2+$ WGP-M $\phi$ versus $\mathrm{M} 2-\mathrm{M} \phi$, which could reflect increased gluconeogenic (GNG) capacity. Glutamine (Gln) uptake as well as the release of glutamate (Glu) (b) and ${ }^{13} \mathrm{C}_{6}$-Glc-derived Glu (c) into the medium were lower in M1-M $\phi$ than $\mathrm{M} 2-\mathrm{M} \phi$ and $\mathrm{M} 2+\mathrm{WGP}-\mathrm{M} \phi$. Glu and ${ }^{13} \mathrm{C}-\mathrm{Glu}$ are presumably exported for cystine uptake via the $\mathrm{X}_{\mathrm{C}-}$ transporter system. We also saw newly synthesized $\mathrm{Gln}\left({ }^{13} \mathrm{C}-\mathrm{Gln}, \mathrm{c}\right)$ to be released into the medium but polarization treatments had little effect on this event. Tryptophan (Trp) uptake was enhanced with depletion of intracellular Trp in M1-M $\phi$ versus M2- and M2+WGP-M $\phi$ (d). This, together with the enhanced buildup of the downstream catabolite quinolinate (QA) in M1-M $\phi$, points to the activation of Trp catabolism but blockade of $\mathrm{NAD}^{+}$synthesis from QA, which are consistent with the overexpression of indoleamine 2,3-dioxygenase 1 (IDO1) [172] and the blockade of quinolinate phosphoribosyltransferase (QPRT) [173] in inflammatory human M $\phi$. QA buildup also occurred in M2+WGP-M $\phi$ but without the enhanced Trp uptake and depletion of intracellular Trp. When CM was present, we saw enhanced ${ }^{13} \mathrm{C}_{6}$-Glc uptake and ${ }^{13} \mathrm{C}$-Lac release $\left(a^{\prime}\right)$, which was independent of the polarization/WGP treatments. In contrast, $\mathrm{CM}$ reduced Gln uptake while reversing Glu release into the medium, particularly for $\mathrm{M} 1-\mathrm{M} \phi\left(\mathrm{b}^{\prime}\right)$. However, $\mathrm{CM}$ enhanced the release of newly synthesized Gln and Glu into the medium ( $\left.\mathrm{c}^{\prime}\right)$, relatively more so for M1-M $\phi$ than for M2-M $\phi$ and M2+WGP-M $\phi$. Moreover, CM enhanced Trp uptake $\left(\mathrm{d}^{\prime}\right)$ and QA buildup $\left(\mathrm{g}^{\prime}\right)$ with reduced Trp accumulation ( $\left.\mathrm{f}^{\prime}\right)$ in $\mathrm{M} 2-\mathrm{M} \phi$ and M2+WGP-M $\phi$ but had little effect on the corresponding events in M1-M $\phi$. 
A
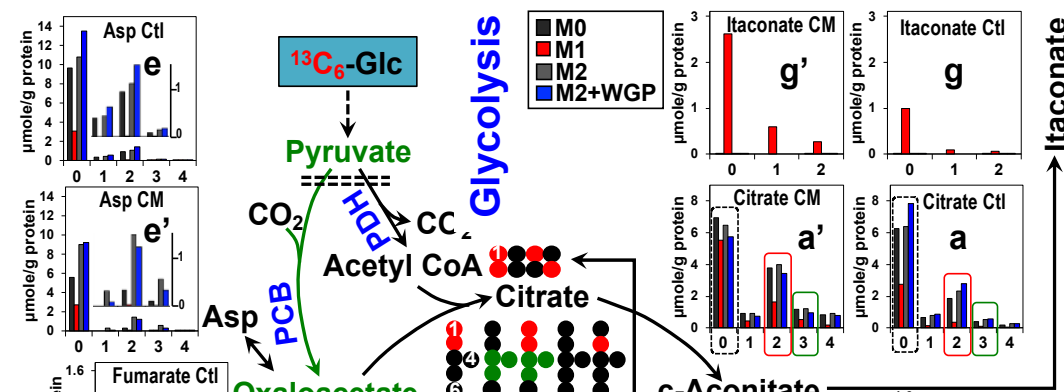

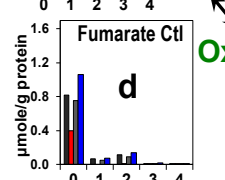
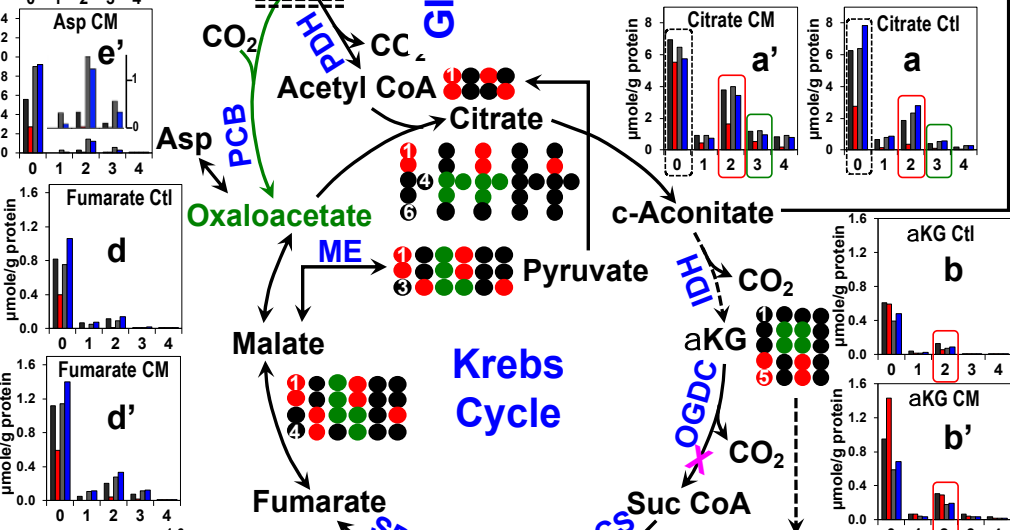

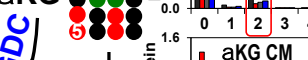
Cycle

(1.6)
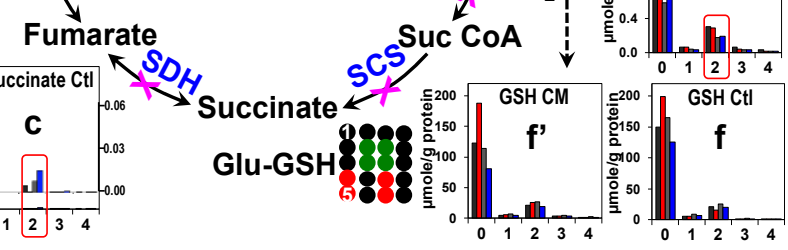

B
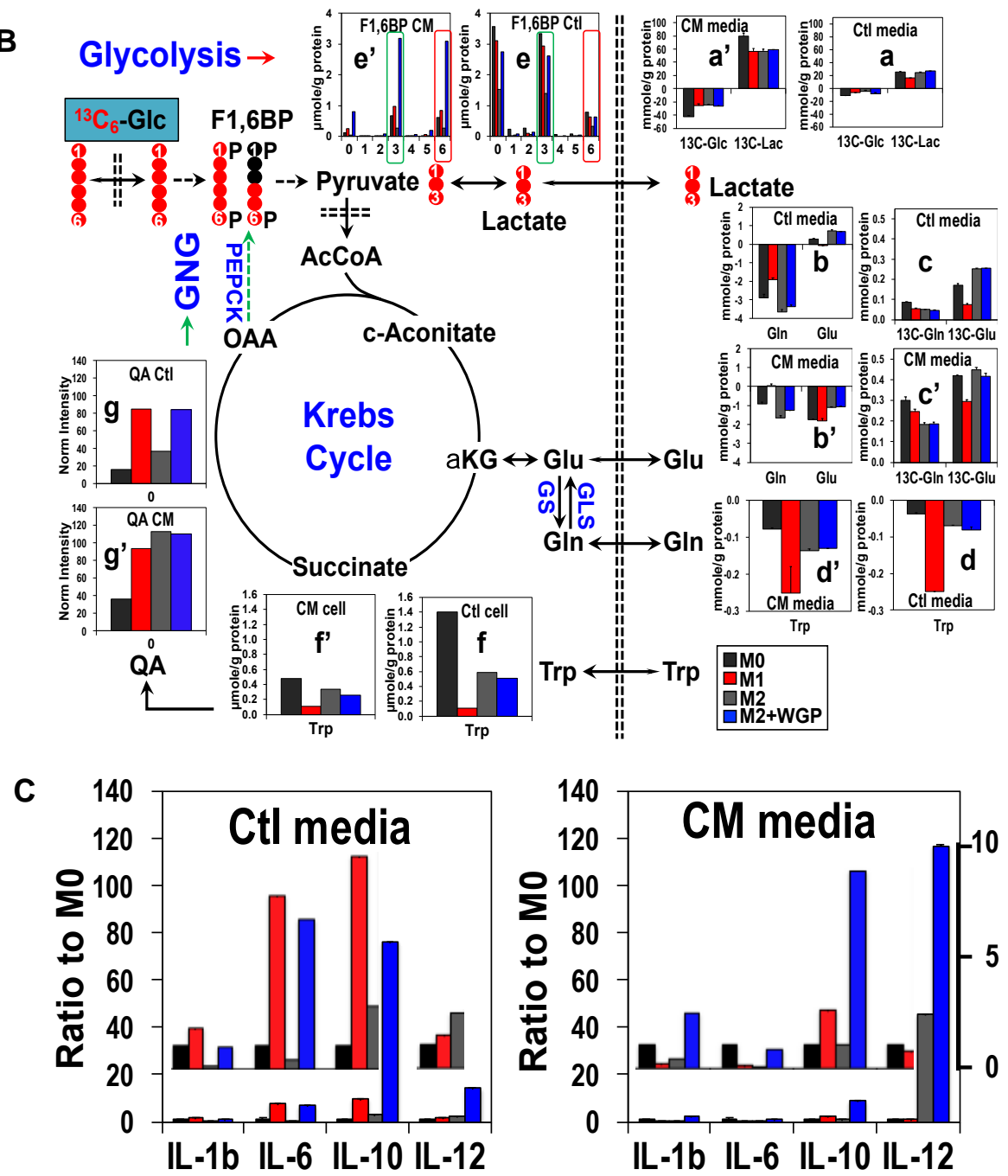

Figure 2. A549 cancer cell conditioned medium alters metabolic response of human macrophage (M $\phi)$ spheroids to polarization and WGP as tracked by SIRM. The 3D M $\phi$ cultures $(n=2)$ were prepared, 
polarized, and treated with ${ }^{13} \mathrm{C}_{6}$-glucose (Glc) as described in the main text. The cell extracts were combined while the medium extracts remained separate for IC-UHR-FTMS analysis. ${ }^{12} \mathrm{C}(\bullet)$ and ${ }^{13} \mathrm{C}$ $(\bullet, \bullet)$ atom tracing through glycolysis, the Krebs cycle, gluconeogenesis (GNG), and Trp catabolism is shown to account for some of the labeled isotopologues of metabolites seen by IC-UHR-FT MS analysis. Red and green boxes in (A) denote labeled species produced respectively by glycolysis and the GNG pathway while black, red, and green boxes in $(\mathbf{B})$ mark ${ }^{12} C_{,}{ }^{12} C_{2}$, and ${ }^{12} C_{3}$ isotopologues of metabolites. Numbers in $\mathrm{X}$-axis refer to the number of ${ }^{13} \mathrm{C}$ atoms. $\approx: \mathrm{M} 0-\mathrm{M} \phi ; \varpi: \mathrm{M} 1-\mathrm{M} \phi ; \varpi: \mathrm{M} 2-\mathrm{M} \phi$; n: M2-M $\phi+$ WGP. (C). Cytokines released into the culture media were measured using the Human Cytokine Magnetic 35-Plex Panel per vendor's protocol (Invitrogen) and the level was ratioed to that of

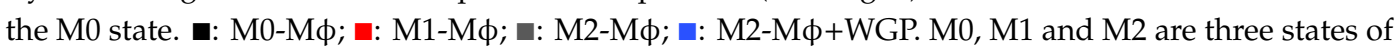
polarization of macrophages as described in the Methods.

To see the treatment effect on the Krebs cycle, we examine the ${ }^{13} \mathrm{C}$ labeling patterns of Krebs cycle metabolites in human $\mathrm{M} \phi$ in response to polarization $\pm \mathrm{CM}$ treatments by IC-UHR-FTMS analysis. Figure $2 \mathrm{~B}$ shows reduced levels of the ${ }^{13} \mathrm{C}_{2}$ - and ${ }^{13} \mathrm{C}_{3}$-isotologues of citrate (a), succinate (c), fumarate (d), and Asp (e) in M1- versus M2- and M2+WGP-M $\phi$, which suggests decreased capacity of the pyruvate dehydrogenase (PDH) and pyruvate carboxylase (PCB)-initiated Krebs cycle, respectively [91]. This is consistent with the compromised Krebs cycle observed in mouse M1-M $\phi$ due to the two breaks at the isocitrate dehydrogenase (IDH) and succinate dehydrogenase (SDH) steps [174-176]. We observed succinate buildup and fumarate depletion expected from the SDH break but did not see citrate buildup and $\alpha$ ketoglutarate $(\alpha K G, \mathbf{b})$ depletion expected from the IDH block in the Krebs cycle. These changes applied only to the ${ }^{12} \mathrm{C}$ (unlabeled) isotopologues, which indicate that they are not derived from ${ }^{13} \mathrm{C}_{6}$-Glc metabolism. Instead, ${ }^{13} \mathrm{C}_{6}$-Glc-related buildup of ${ }^{13} \mathrm{C}_{2}-\alpha K G(b)$ and depletion of ${ }^{13} \mathrm{C}_{2}$-succinate (c) in M1-M $\phi$ versus M2- and M2+WGP-M $\phi$ were evident, which is likely due to a block at the oxoglutarate dehydrogenase (OGDH) and/or succinyl CoA synthetase (SCS) step. Despite the attenuated Krebs cycle capacity, ${ }^{13} \mathrm{C}$ labeling and/or the levels of the byproducts, itaconate $(\mathrm{g})$ and glutathione $(\mathrm{GSH}, \mathrm{f})$, were elevated in $\mathrm{M} 1-\mathrm{M} \phi$. Itaconate is known to be elicited by LPS in inflammatory M $\phi$ to inhibit microbial growth [177], but its excess buildup was also shown to be anti-inflammatory $[178,179]$. GSH has been shown to stimulate pro-inflammatory activity while relieving oxidative stress in RAW 264.7 macrophages [180]. Moreover, we saw multiple CM-dependent changes in the Krebs cycle, notably the enhanced buildup of both unlabeled and ${ }^{13} \mathrm{C}$-itaconate $\left(\mathrm{g}^{\prime}\right)$ as well as the less blocked Krebs cycle in $\mathrm{M} 1-\mathrm{M} \phi$ as evidenced by the less depletion of ${ }^{13} \mathrm{C}$ labeled Krebs cycle products $\left(\mathrm{a}^{\prime}, \mathrm{c}^{\prime}\right.$, and $\left.\mathrm{d}^{\prime}\right)$ relative to $\mathrm{M} 2-\mathrm{M} \phi$. These changes could signify a shift towards the M2-like phenotype, which is consistent with the CM-induced decrease in the release of pro-inflammatory cytokines IL-1 $\beta$ and IL-6 by M1-M $\phi$ as shown in Figure $2 \mathrm{C}$. Also shown was the stimulation of IL-1 $\beta$ and IL- 6 release into the M2-M $\phi$ media by WGP, which points to a shift from M2 to an M1-like phenotype. Further consistent with the M2 to M1 switch was the enhanced release of IL-10 into the M2-M $\phi$ media by WGP. IL-1 $\beta$, IL-10, and IL-12 were previously shown to be markers of human M1-M $\phi$ in 2D cultures [172]. Here we showed this to be the case for IL-1 $\beta$ and IL-10 but not for IL-12 in M1-M $\phi$ as spheroid cultures. IL-12 release by M2-M $\phi$ was stimulated by WGP or CM and further enhanced by CM+WGP. Although known as a pro-inflammatory cytokine, IL-12 can also have an anti-inflammatory role during secondary immune responses [181]. Further studies are needed to see if how IL-12 alters immune functions in response to WGP and/or CM treatments.

It should be noted that M1 and M2 designations do not fully represent the complexity of human macrophage phenotypes [182], nor can they fully describe the WGP effect on $M \phi$ polarization in spheroid cultures. Based on the above data, WGP induced a mixed phenotype in human M2-M $\phi$ spheroids, with some M1-like features (e.g., QA buildup; enhanced IL-1 $\beta / I L-6$ release) while retaining a large part of the M2 properties (e.g., enhanced Gln uptake/Krebs cycle activity). 


\section{Co-Culturing of Cancer Cell with Mф Alters Metabolic Response of Human M2-Mф Spheroids to WGP}

As described above and in Table 1, direct cell-cell interactions and altered architecture of tumors can impact cancer and stromal cell metabolism. We mixed A549 cells with differentiated M $\phi$ from patient UK96 in a 1:1 ratio as spheroids and subjected the co-cultures in parallel with spheroids generated from isolated $\mathrm{A} 549$ or $\mathrm{M} \phi$ cells to the same polarization and WGP treatment as described above except for employing a triple tracer cocktail $0.2 \%{ }^{2} \mathrm{H}_{7}-\mathrm{Glc}+2 \mathrm{mM}^{13} \mathrm{C}_{5}-\mathrm{Gln}+78 \mu \mathrm{M}{ }^{15} \mathrm{~N}_{2}$-Trp for $24 \mathrm{~h}$. The incorporation of ${ }^{2} \mathrm{H},{ }^{13} \mathrm{C}$, and/ or ${ }^{15} \mathrm{~N}$ into various metabolites was resolved and quantified by IC-UHR-FTMS $[107,170,183,184]$. Figure $3 \mathrm{~A}$ illustrates the tracing of ${ }^{2} \mathrm{H}_{7}$-Glc via glycolysis and the Krebs cycle, of ${ }^{13} \mathrm{C}_{5}$-Gln via glutaminolysis, the Krebs cycle, and GNG, and of ${ }^{15} \mathrm{~N}_{2}$-Trp via the kynurenine (KYN) pathway $[173,185]$ in the pure cultures and co-culture under M2 polarization \pm WGP treatment. We found that M2-M $\phi$ spheroids ( $\square$ ) had a higher capacity for incorporating ${ }^{2} \mathrm{H}(\mathrm{D})$, ${ }^{13} \mathrm{C}$, and/or ${ }^{15} \mathrm{~N}$ into glycolytic (e.g., F1,6BP, a), Krebs cycle (e.g., citrate, b; $\alpha \mathrm{KG}$, c; and Glu, e), and Trp metabolites (e.g., QA, f) than A549 spheroids ( $\square$ ). The production of ${ }^{13} \mathrm{C}-\mathrm{F} 1,6 \mathrm{BP}{ }^{13} \mathrm{C}_{5}$-Gln from signified GNG activity $(\rightarrow)$. All of these capacities were further enhanced by the WGP treatment $(\square$, $\mathrm{a}^{\prime}-\mathrm{c}^{\prime}$ and $\left.\mathrm{e}^{\prime}\right)$. WGP also increased the buildup of ${ }^{13} \mathrm{C}$-itaconate in M2-M $\phi$ but it had an opposite effect in A549 spheroids ( $\left.d^{\prime}\right)$. The WGP effect on the Krebs cycle and GNG in M2-M $\phi$ spheroids recapitulated those traced by ${ }^{13} \mathrm{C}_{6}$-Glc in Figure 2 while the enhanced buildup of ${ }^{15} \mathrm{~N}$-QA in WGP treated M2-M $\phi$ spheroids verified altered Trp catabolism reasoned in the ${ }^{13} \mathrm{C}_{6}$-Glc study.

Co-culturing of A549 and M2-M $\phi(\square)$ did not have a notable effect on glycolysis (a) but enhanced the buildup of ${ }^{13} C$ and/or D-labeled $\left(C^{*} D_{x}, b\right)$ citrate and ${ }^{15} N-Q A$ (f) while depleting $C^{*} D_{x}-\alpha K G(c)$, ${ }^{13} \mathrm{C},{ }^{15} \mathrm{~N}$, and/or D-labeled $\left(\mathrm{C}^{*} \mathrm{ND}_{\mathrm{x}}\right)$ Glu (e), and $\mathrm{C}^{*} \mathrm{D}_{\mathrm{x}}$-itaconate $(\mathrm{d})$ relative to the A549 monoculture. These metabolic interactions were significantly modified by the WGP treatment ( $)$. WGP greatly suppressed ${ }^{13} \mathrm{C}$ and/or D incorporation into $\mathrm{F} 1,6 \mathrm{BP}\left(\mathrm{a}^{\prime}\right)$, citrate $\left(\mathrm{b}^{\prime}\right)$, while having an opposite effect on that into $\alpha \mathrm{KG}\left(\mathrm{c}^{\prime}\right) /$ itaconate $\left(\mathrm{d}^{\prime}\right)$, and ${ }^{15} \mathrm{~N}$ incorporation into $\mathrm{QA}\left(\mathrm{f}^{\prime}\right)$ in the co-culture (Figure $\left.3 \mathrm{~A}\right)$. These effects were either opposite (for F1,6BP, Figure 2A) or absent in the CM+WGP-treated M2-M $\phi$ (for QA, Figure 2A; citrate, $\alpha \mathrm{KG}$, and itaconate, Figure 2B), which points to the importance of cell-cell contact in mediating these effects. Such co-culturing+WGP effect on citrate and $\alpha K G$ was akin to the CM-induced responses in M1-M $\phi$ ( $a^{\prime}$ versus $b^{\prime}$, Figure $2 B$ ), which could reflect a break at the OGDC or SCS step. This, together with the enhanced buildup of itaconate and QA suggests that WGP retained its ability to repolarize the $\mathrm{M} 2$ to $\mathrm{M} 1$ phenotypes in the co-culture but also enhanced further the M2 phenotype based on the F1,6BP response. The mixed M1- and M2-type metabolic responses induced by WGP in both mono- and co-cultures of M2-M $\phi$ were consistent with the expression of both M1 (HLA-DR) and M2 (CD-206) markers (Figure 3B). WGP treatment also induced the expression of another M1 marker (IDO1) and apoptotic marker caspase 3 (Figure 3C), which implicates killing action via $\mathrm{M} 1$ repolarization.

The WGP's action on the metabolic and immune responses in the 3D cancer cell-M $\phi$ co-culture can be related to those of the PD OTC of tumor tissues [186] to help resolve the contribution of cancer cells or tumor-associated $\mathrm{M} \phi$ (TAM) to the overall responses. For example, the WGP-induced buildup of glucose-derived F1,6BP in the responsive tumor tissue (Figure 2B in Fan et al. [186]) could have originated from $\mathrm{M} \phi$ not in direct contact with cancer cells (Figure 2A), as this response was not evident in the mono-cultures of cancer cells and $\mathrm{M} 2-\mathrm{M} \phi$ or in their co-culture with cell contact (Figure 3A). By a similar reasoning, the WGP-induced accumulation of unlabeled itaconate in the responsive tumor tissue (Figure 2L in [186]) was likely a result of enhanced Gln, instead of Glc, metabolism in cancer cells/M $\phi$ alone and/or cancer cells-TAM that are in direct interactions (Figure 3A). This interpretation was afforded with very limited samples using the mSIRM approach, where the fate of Glc and Gln were tracked simultaneously and more robustly than the single tracer-based SIRM approach. 

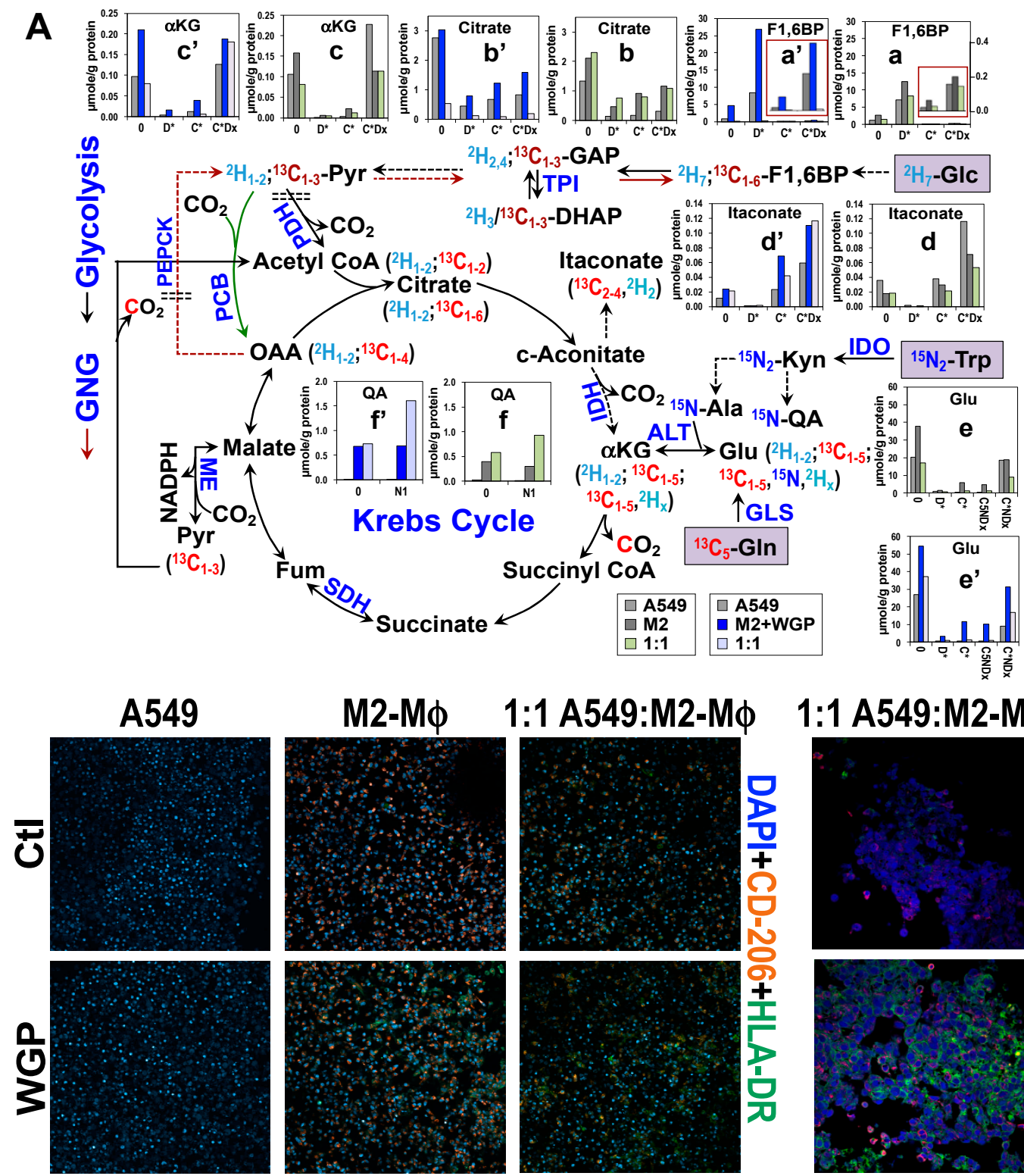

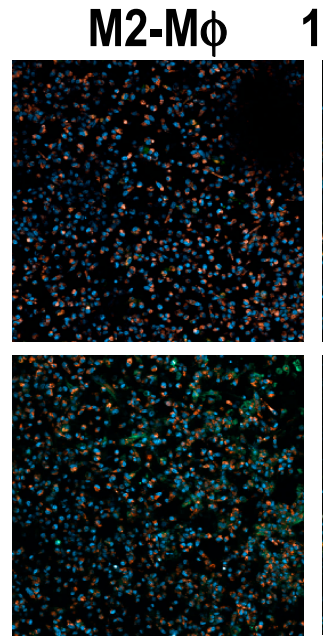

B

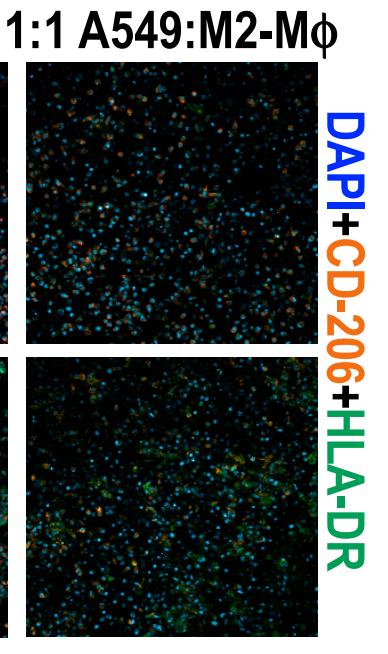

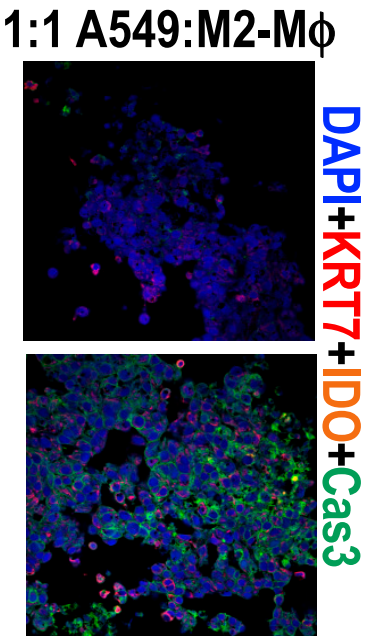

C

Figure 3. A549 cancer cell co-culturing alters metabolic and immune marker responses of human M2-M $\phi$ spheroids to WGP as tracked by mSIRM. The 3D single or co-cultures (1:1 A549:M $\phi)(\mathrm{n}=2)$ in (A) were treated with IL-4+IL-13 for $3 \mathrm{~d} \pm$ WGP as in Figure 2 except with 2H7-Glc+13C5-Gln+15N2-Trp as tracers in the last $24 \mathrm{~h}$. The cell extracts were combined for IC-UHR-FTMS analysis. $2 \mathrm{H} / 13 \mathrm{C} / 15 \mathrm{~N}$ atom tracing through glycolysis, the Krebs cycle, GNG, and Trp catabolism is shown to account for some of the labeled isotopologues of metabolites seen by IC-UHR-FTICRMS analysis. Red boxes denote 13C labeled fructose-1,6-bisphosphate (F1,6BP) produced by the GNG pathway. $₫:$ A549; $\varpi:$ M2-M $\phi ;::$ A549:M2-Mф 1:1; : : M2+WGP; : A549:M2-M申 1:1+WGP; D*: total 2H; C*: total 13C; N: 15N; Cx: 13Cx; Dx: 2H0-x; GAP: glyceraldehyde-3-phosphate; DHAP: dihydroxyacetone-3-phpsphate; Pyr: pyruvate; $\alpha$ KG: $\alpha$ ketoglutarate; Fum: fumarate; OAA: oxaloacetate; Kyn: kynurenine; QA: quinolinate; TPI: triosephosphate isomerase; PDH: pyruvate dehydrogenase; PCB: pyruvate carboxylase; ALT: alanine transaminase; SDH: succinate dehydrogenase; ME: malic enzyme; PEPCK: phosphoenolpyruvate carboxykinase; IDO: indoleamine 2,3-dioxygenase; GLS: glutaminase. In (B), treated mono- and co-cultures were stained as live cells for M2 (CD-206), M1 (HLA-DR), and nuclear (DAPI) markers while in (C), cells were fixed in $4 \%$ paraformaldehyde before staining for cancer cell (KRT7), M1 (IDO1), and apoptotic caspase 3 (Cas3) markers. 


\section{Concluding Remarks and Future Directions}

To achieve systems biochemical understanding of tissue heterogeneity at the cellular level, it would be ideal to perform SIRM, proteomic, and genomic analyses at the individual cell level in live tissues in situ $[108,159,187,188]$. However, this is not yet technically feasible. Alternative strategies that combine techniques at different scales should therefore be considered.

Subcellular imaging of cells and tissues has long been feasible with epi and confocal fluorescence microscopy. Recent advancement in super resolution imaging can achieve image resolution of $50 \mathrm{~nm}$ or less [189-193]. In addition, free versus bound concentrations of metabolites can be discriminated in cells by fluorescence lifetime imaging microscopy (FLIM) [158,194,195]. However, microscopy-based metabolic imaging requires the use of fluorescent probes such as NBD-glucose for measuring glucose uptake [58-60], with the exception of a few metabolites that have intrinsic fluorescence (e.g., FADH2, $\mathrm{NAD}(\mathrm{P}) \mathrm{H})$ [196]. In addition, this approach cannot resolve stable isotopes and is currently low in metabolic coverage. More recently, high resolution confocal Raman imaging has become practical with single cell resolution. As the Raman effect depends on bond vibrations, signals are sensitive to isotopic substitutions, especially for D replacement of H [197-199]. Although not directly useful for metabolic imaging, the emerging DSP technique can be used to measure the expression of metabolic genes and proteins in situ at single cell type resolution. Such information can help resolve the contribution of single cell types to the metabolic activity measured by SIRM and protein expression analyzed by RPPA $[107,200]$ in tissues with no spatial discrimination.

NMR-based imaging (NMRI) does not require optical probes, has greater depth than optical imaging, is capable of wider metabolite coverage with stable isotope resolution [201-206], and is fully compatible with in vivo real-time measurements including metabolic rates (e.g., unidirectional rate of ATP synthesis [207,208]). However, its utility is limited by much poorer resolution (regional level) and lower sensitivity. The sensitivity of stable isotope-resolved MRI can be substantially improved by the use of hyperpolarized substrates [209-211], post-acquisition processing [11], and proton detection [201,212-214] but still at relatively low spatial resolution and metabolic coverage (typically < 10 metabolites).

MALDI-based mass spectrometric imaging can achieve high resolution in tissue, at either regional resolution comparable to DSP or at the single cell $(1-10 \mu \mathrm{m})$ resolution with new developments [215-218]. These technologies are particularly valuable for resolving spatial heterogeneities of immobile lipids, proteins, and glycoproteins, such as glycosylated surface protein and extracellular matrix peptides $[219,220]$.

DSP coupled with SIRM approach can be applied to spheroid and organoids for resolving their metabolic heterogeneities. As we have shown, it is also feasible to use SIRM to profile metabolic activities in mono- and co-spheroid cultures of different cell types to learn about their metabolic distinction and interactions, which can in turn help determine individual cell types' contribution to bulk tissue metabolism. We have demonstrated that the SIRM profile of human macrophages is altered by human lung A549 cancer cell conditioned media (which contains excreted diffusible compounds), and by coculturing with A549 cell. However, the profiles of CM versus co-culture are not identical, indicating that the cell-cell contacts induce altered metabolism differently from the diffusible substrates. This strategy is greatly facilitated by the new mSIRM technology, which we have demonstrated as a preliminary investigation. Future organoid and matched tissue studies that integrate mSIRM with metabolic imaging, DSP, as well as single-cell 'omics, should achieve global mapping of metabolic activity at the single cell levels before single-cell SIRM becomes a reality. New informatics and statistical analyses that enable robust and efficient information retrieval as well as integrated data interpretation from such studies will also need to be developed.

\section{Materials and Methods}

Lung tissues were collected from consented patients at the operating room within five minutes of surgical resection and placed in DMEM media in accordance with HIPAA regulations. All tissue 
experiments were carried out via a protocol approved by the University of Kentucky Institutional Review Board (IRB) (IRB 14-0288-F6A). The pair of tissues were thinly sliced to $<1 \mathrm{~mm}$ thickness as previously described [221,222]. Tissues for the tumor and adjacent healthy lung were preserved in formalin and embedded in paraffin for pathological analyses

\subsection{HEE Staining}

Thin paraffin-embedded sections of tissues were H\&E stained as per standard protocol. A variety of cell types can be identified from size and shape in the cancer tissue, including transformed epithelia, plasma cells, infiltrating lymphocytes and macrophages, as shown in Figure 1A.

\subsection{DSP (Nanostring)}

FFPE tissue slices from human NSCLC were cut to $5 \mu \mathrm{m}$ and sent to NanoString (Seattle, WA, USA) for staining for different cellular markers, including the nuclei (for counting cells), and fluorescent antibodies to keratin (pan cancer markers), CD8 (T cell marker), and CD68 (macrophage marker).

Protein markers in regions of interest of the FFPE tissue sections were quantified by counting the cleaved oligos using Nanostring's nCounter. The oligo-conjugated antibodies were prepared and validated by Nanostring. ROIs in fixed tissues were selected based on desired markers for cell nuclei and markers for T-cells, macrophages, and in consultation with a pathologist (Dr. T. Bocklage) before automated analysis on Nanostring's GeoMx system and nCounter.

\subsection{Monocytes Isolation, Differentiation, and Polarization}

Monocytes were isolated from whole human peripheral blood of a male (UK96) and a female (UK94) donors (both >60 years of age) using the RosetteSep ${ }^{\mathrm{TM}}$ human monocyte enrichment cocktail kit (StemCell, Cambridge, MA). Monocytes were differentiated in 6-well plates (Nunclon, ThermoFisher Scientific, USA) for six days in monocytes differentiation medium (MDM) containing DMEM, 10\% FBS, $10 \mathrm{mM}$ glucose, $2 \mathrm{mM}$ Gln, $1 X$ Anti-anti, and $50 \mathrm{ng} / \mathrm{mL} \mathrm{CSF}-1$ at $37{ }^{\circ} \mathrm{C} / 5 \% \mathrm{CO}_{2}$ at a density of $3-5 \times 10^{6}$ cells per well before polarization. Cells were maintained in MDM (M0) or polarized to either M1-like with $100 \mathrm{ng} / \mathrm{mL}$ LPS + $20 \mathrm{ng} / \mathrm{mL}$ IFN $\gamma$ or to M2-like subtype with $20 \mathrm{ng} / \mathrm{mL}$ each IL-4 + IL-13 for 2 to 3 days.

\subsection{SIRM of Macrophage Spheroids and A549-Macrophage Organoid Cultures}

Human macrophages were isolated as described above were induced to form spheroids in 6-well plates in organoid medium and were treated with $10 \mathrm{mM}{ }^{13} \mathrm{C}_{6}$-glucose for $24 \mathrm{~h}$ before harvesting and immediate extraction for polar, non-polar and protein fractions using our $\mathrm{CH}_{3} \mathrm{CN} / \mathrm{H}_{2} \mathrm{O} / \mathrm{CHCl}_{3}$ solvent partitioning method $[223,224]$. After lyophilization and reconstitution, polar metabolites were identified and quantified by IC-FTMS and NMR according to our untargeted workflow that can resolve multiple tracer atoms (e.g., ${ }^{2} \mathrm{H},{ }^{13} \mathrm{C}$, and ${ }^{15} \mathrm{~N}$ ) in the same metabolite $[91,92,170,225-228]$. For co-cultures, macrophages were mixed with an equal number of A549 cells and induced to form spheroids and incubated for $24 \mathrm{~h}$ with medium containing $10 \mathrm{mM}^{2} \mathrm{H}_{7}$-glucose $+70 \mu \mathrm{M}^{15} \mathrm{~N}_{2}$ tryptophan $+2 \mathrm{mM}^{13} \mathrm{C}_{5}$ glutamine. The organoids were harvested and extracted for analysis as described for the macrophages.

Author Contributions: Conceptualization, T.W.-M.F. and A.N.L.; methodology, Y.C., R.M.H., and T.W.-M.F.; formal analysis, T.W.-M.F. and R.M.H.; investigation, Y.C., T.W.-M.F., and R.M.H.; writing-original draft preparation, A.N.L. and T.W.-M.F.; writing-review and editing, A.N.L., T.W.-M.F., Y.C., and R.M.H.; funding acquisition, A.N.L., T.W.-M.F. and R.M.H. All authors have read and agreed to the published version of the manuscript.

Funding: This work was supported by 1P01CA163223-01A1, 1U24DK097215-01A1, Markey Cancer Center Support Grant pilot funds, the Carmen L. Buck Chair in Oncology (to A.N.L.), and the Edith D. Gardner Chair in Cancer Research (to T.W-M.F.). NMR. and MS. were recorded using the Metabolism Shared Resources supported in part by P30CA177558 (to B.M. Evers). 
Acknowledgments: We thank Matthew Purdom and Therese Bocklage for valuable discussions on tissue pathology; Qiushi Sun, Jessica Macedo, James Sledziona and Huan Song for expert technical assistance; and Liang Zhang of NanoString Technologies for expert help in generating the immunohistochemical images.

Conflicts of Interest: The authors declare no conflict of interest.

\section{Abbreviations}

CAF cancer associated fibroblast; CM Conditioned Medium; CSF1 colony stimulating factor 1; DSP digital spatial profiling; ECM extracellular matrix; EMT epithelial mesenchyme transition; FFPE formalin fixed paraffin embedded; Glc D-glucose; ${ }^{13} \mathrm{C}_{6}$-Glc glucose enriched with ${ }^{13} \mathrm{C}$ at all six carbon positions; H\&E hematoxylin and eosin; IC-UHR-FT MS ion chromatography-ultrahigh resolution mass spectrometry; MALDI matrix assisted laser desorption ionization; M $\phi$ macrophages; NSCLC non-small cell lung cancer; NSG Nod Scid Gamma; PDX patient-derived xenograft; RPPA reverse phase protein array; scRNAseq single cell RNA sequencing; SIRM Stable Isotope Resolved Metabolomics; TAM tissue associated macrophage; TME tumor microenvironment; WGP whole glucan particles; UHR-FTMS ultra high resolution Fourier transform mass spectrometry.

\section{References}

1. Voigt, W.; Manegold, C.; Pilz, L.; Wu, Y.-L.; Mullauer, L.; Pirker, R.; Filipits, M.; Niklinski, J.; Petruzelka, L.; Prosch, H. Beyond tissue biopsy: A diagnostic framework to address tumor heterogeneity in lung cancer. Curr. Opin. Oncol. 2020, 32, 68-77. [CrossRef] [PubMed]

2. Reina-Campos, M.; Diaz-Meco, M.T.; Moscat, J. The complexity of the serine glycine one-carbon pathway in cancer. J. Cell Biol. 2020, 219, e20190722. [CrossRef] [PubMed]

3. Lukina, M.M.; Shimolina, L.E.; Kiselev, N.M.; Zagainov, V.E.; Komarov, D.V.; Zagaynova, E.V.; Shirmanova, M.V. Interrogation of tumor metabolism in tissue samples ex vivo using fluorescence lifetime imaging of NAD(P)H. Methods Appl. Fluoresc. 2020, 8, 0140002. [CrossRef] [PubMed]

4. Liu, D.; Paczkowski, P.; Mackay, S.; Ng, C.; Zhou, J. Single-Cell Multiplexed Proteomics on the IsoLight Resolves Cellular Functional Heterogeneity to Reveal Clinical Responses of Cancer Patients to Immunotherapies. Methods Mol. Biol. 2020, 2055, 413-431. [CrossRef]

5. Kudou, M.; Nakanishi, M.; Kuriu, Y.; Murayama, Y.; Arita, T.; Kishimoto, M.; Konishi, E.; Goto, M.; Yamada, K.; Otsuji, E. Value of intra-tumor heterogeneity evaluated by diffusion-weighted MRI for predicting pathological stages and therapeutic responses to chemoradiotherapy in lower rectal cancer. J. Cancer 2020, 11, 168-176. [CrossRef]

6. Kim, J.Y.; Kim, J.J.; Hwangbo, L.; Lee, J.W.; Lee, N.K.; Nam, K.J.; Choo, K.S.; Kang, T.; Park, H.; Son, Y.; et al. Diffusion-weighted MRI of estrogen receptor-positive, HER2-negative, node-negative breast cancer: Association between intratumoral heterogeneity and recurrence risk. Eur. Radiol. 2020, 30, 66-76. [CrossRef] [PubMed]

7. Eng, J.; Thibault, G.; Luoh, S.-W.; Gray, J.W.; Chang, Y.H.; Chin, K. Cyclic Multiplexed-Immunofluorescence (cmIF), a Highly Multiplexed Method for Single-Cell Analysis. Methods Mol. Biol. 2020, 2055, 521-562. [CrossRef]

8. Seth Nanda, C.; Venkateswaran, S.V.; Patani, N.; Yuneva, M. Defining a metabolic landscape of tumours: Genome meets metabolism. Br. J. Cancer 2019, 122, 136-149. [CrossRef]

9. Sato, T.; Yoo, S.; Kong, R.; Sinha, A.; Chandramani-Shivalingappa, P.; Patel, A.; Fridrikh, M.; Nagano, O.; Masuko, T.; Beasley, M.B.; et al. Epigenomic Profiling Discovers Trans-lineage SOX2 Partnerships Driving Tumor Heterogeneity in Lung Squamous Cell Carcinoma. Cancer Res. 2019, 79, 6084-6100. [CrossRef]

10. Leung, J.Y.; Chia, K.; Ong, D.S.T.; Taneja, R. Interweaving Tumor Heterogeneity into the Cancer Epigenetic/Metabolic Axis. Antioxid. Redox Signal. 2019. [CrossRef]

11. Kishimoto, S.; Brendert, J.R.; Crooks, D.R.; Matsumoto, S.; Seki, T.; Oshima, N.; Merkle, H.; Lin, P.; Reed, G.; Chen, A.P.; et al. Imaging of glucose metabolism by 13C-MRI distinguishes pancreatic cancer subtypes in mice. eLife 2019, 8, e46312. [CrossRef] [PubMed]

12. Januskeviciene, I.; Petrikaite, V. Heterogeneity of breast cancer: The importance of interaction between different tumor cell populations. Life Sci. 2019, 239, 117009. [CrossRef] [PubMed]

13. Nguyen, Q.H.; Pervolarakis, N.; Blake, K.; Ma, D.; Davis, R.T.; James, N.; Phung, A.T.; Willey, E.; Kumar, R.; Jabart, E.; et al. Profiling human breast epithelial cells using single cell RNA sequencing identifies cell diversity. Nat. Commun. 2018, 9, 2028. [CrossRef] [PubMed] 
14. Young, A.; Mittal, D.; Stagg, J.J.; Smyth, M.J. Targeting Cancer-Derived Adenosine: New Therapeutic Approaches. Cancer Discov. 2014, 4, 879-888. [CrossRef] [PubMed]

15. Gordon, S.R.; Maute, R.L.; Dulken, B.W.; Hutter, G.; George, B.M.; McCracken, M.N.; Gupta, R.; Tsai, J.M.; Sinha, R.; Corey, D.; et al. PD-1 expression by tumour-associated macrophages inhibits phagocytosis and tumour immunity. Nature 2017, 545, 495-499. [CrossRef]

16. Akbar, S.; Peikari, M.; Salama, S.; Panah, A.Y.; Nofech-Mozes, S.; Martel, A.M. Automated and Manual Quantification of Tumour Cellularity in Digital Slides for Tumour Burden Assessment. Sci. Rep. 2019, 9, 14099. [CrossRef]

17. Smits, A.J.J.; Kummer, J.A.; de Bruin, P.C.; Bol, M.; van den Tweel, J.G.; Seldenrijk, K.A.; Willems, S.M.; Offerhaus, G.J.A.; de Weger, R.A.; van Diest, P.J.; et al. The estimation of tumor cell percentage for molecular testing by pathologists is not accurate. Mod. Pathol. 2013, 27, 168-174. [CrossRef]

18. Fukumura, D.; Duda, D.G.; Munn, L.L.; Jain, R.K. Tumor Microvasculature and Microenvironment: Novel Insights Through Intravital Imaging in Pre-Clinical Models. Microcirculation 2010, 17, 206-225. [CrossRef]

19. Schroeder, T.; Yuan, H.; Viglianti, B.L.; Peltz, C.; Asopa, S.; Vujaskovic, Z.; Dewhirst, M.W. Spatial Heterogeneity and Oxygen Dependence of Glucose Consumption in R3230Ac and Fibrosarcomas of the Fischer 344 Rat. Cancer Res. 2005, 65, 5163-5171. [CrossRef]

20. Sonveaux, P.; Végran, F.; Schroeder, T.; Wergin, M.C.; Verrax, J.; Rabbani, Z.N.; De Saedeleer, C.J.; Kennedy, K.M.; Diepart, C.; Jordan, B.F.; et al. Targeting lactate-fueled respiration selectively kills hypoxic tumor cells in mice. J. Clin. Investig. 2008, 118, 3930-3942. [CrossRef]

21. Asp, M.; Giacomello, S.; Larsson, L.; Wu, C.; Furth, D.; Qian, X.; Wardell, E.; Custodio, J.; Reimegard, J.; Salmen, F.; et al. A Spatiotemporal Organ-Wide Gene Expression and Cell Atlas of the Developing Human Heart. Cell 2019, 179, 1647-1660. [CrossRef] [PubMed]

22. Baccin, C.; Al-Sabah, J.; Velten, L.; Helbling, P.M.; Grunschlager, F.; Hernandez-Malmierca, P.; Nombela-Arrieta, C.; Steinmetz, L.M.; Trumpp, A.; Haas, S. Combined single-cell and spatial transcriptomics reveal the molecular, cellular and spatial bone marrow niche organization. Nat. Cell Biol. 2019, 22, 38-48. [CrossRef]

23. Zhang, Q.; He, Y.; Luo, N.; Patel, S.J.; Han, Y.; Gao, R.; Modak, M.; Carotta, S.; Haslinger, C.; Kind, D.; et al. Landscape and Dynamics of Single Immune Cells in Hepatocellular Carcinoma. Cell 2019, 179, 829-845. [CrossRef] [PubMed]

24. Junttila, M.R.; De Sauvage, F.J. Influence of tumour micro-environment heterogeneity on therapeutic response. Nature 2013, 501, 346-354. [CrossRef] [PubMed]

25. Guzman-Herrera, A.; Mao, Y. Polarity during tissue repair, a multiscale problem. Curr. Opin. Cell Biol. 2020, 62, 31-36. [CrossRef] [PubMed]

26. Bryant, D.M.; Mostov, K.E. From cells to organs: Building polarized tissue. Nat. Rev. Mol. Cell Biol. 2008, 9 , 887-901. [CrossRef]

27. Connolly, J.L.; Schnitt, S.J.; Wang, H.H.; Longtine, J.A.; Dvorak, A.; Dvorak, H.F. Tumor Structure and Tumor Stroma Generation, 6th ed.; BC Decker: Hamilton, ON, Canada, 2003.

28. Hanahan, D.; Weinberg, R.A. Hallmarks of Cancer: The Next Generation. Cell 2011, 144, 646-674. [CrossRef]

29. Marusyk, A.; Polyak, K. Tumor heterogeneity: Causes and consequences. Biochim. Biophys. Acta 2010, 1805, 105-117. [CrossRef]

30. Marusyk, A.; Almendro, V.; Polyak, K. Intra-tumour heterogeneity: A looking glass for cancer? Nat. Rev. Cancer 2012, 12, 323-334. [CrossRef]

31. Bredholt, G.; Mannelqvist, M.; Stefansson, I.M.; Birkeland, E.; Bø, T.H.; Øyan, A.M.; Trovik, J.; Kalland, K.-H.; Jonassen, I.; Salvesen, H.B.; et al. Tumor necrosis is an important hallmark of aggressive endometrial cancer and associates with hypoxia, angiogenesis and inflammation responses. Oncotarget 2015, 6, 39676-39691. [CrossRef]

32. Faubert, B.; DeBerardinis, R.J. Analyzing Tumor Metabolism In Vivo. Annu. Rev. Cancer Biol. 2017, 1, 99-117. [CrossRef]

33. Zhang, H.; Fillmore Brainson, C.; Koyama, S.; Redig, A.J.; Chen, T.; Li, S.; Gupta, M.; Garcia-de-Alba, C.; Paschini, M.; Herter-Sprie, G.S.; et al. Lkb1 inactivation drives lung cancer lineage switching governed by Polycomb Repressive Complex 2. Nat. Commun. 2017, 8, 14922. [CrossRef]

34. Lamouille, S.; Xu, J.; Derynck, R. Molecular mechanisms of epithelial-mesenchymal transition. Nat. Rev. Mol. Cell Biol. 2014, 15, 178-196. [CrossRef] [PubMed] 
35. Aguilar, E.; Marin de Mas, I.; Zodda, E.; Marin, S.; Morrish, F.; Selivanov, V.; Meca-Cortes, O.; Delowar, H.; Pons, M.; Izquierdo, I.; et al. Metabolic Reprogramming and Dependencies Associated with Epithelial Cancer Stem Cells Independent of the Epithelial-Mesenchymal Transition Program. Stem Cells 2016, 34, 1163-1176. [CrossRef] [PubMed]

36. Graf, T.; Enver, T. Forcing cells to change lineages. Nature 2009, 462, 587-594. [CrossRef] [PubMed]

37. Orkin, S.H.; Zon, L.I. Hematopoiesis: An evolving paradigm for stem cell biology. Cell 2008, 132, 631-644. [CrossRef]

38. Stadhouders, R.; Filion, G.J.; Graf, T. Transcription factors and 3D genome conformation in cell-fate decisions. Nature 2019, 569, 345-354. [CrossRef]

39. Forbes, M. Cell Structure. In Cell Physiology Source Book; Sperelakis, N., Ed.; Academic Press: Cambridge, MA, USA, 2012; pp. 67-83.

40. Kyrochristos, I.D.; Ziogas, D.E.; Goussia, A.; Glantzounis, G.K.; Roukos, D.H. Bulk and Single-Cell Next-Generation Sequencing: Individualizing Treatment for Colorectal Cancer. Cancers 2019, 11, 1809. [CrossRef]

41. Close, H.J.; Stead, L.F.; Nsengimana, J.; Reilly, K.A.; Droop, A.; Wurdak, H.; Mathew, R.K.; Corns, R.; Newton-Bishop, J.; Melcher, A.A.; et al. Expression profiling of single cells and patient cohorts identifies multiple immunosuppressive pathways and an altered NK cell phenotype in glioblastoma. Clin. Exp. Immunol. 2019, 200, 33-44. [CrossRef]

42. Al-Sabah, J.; Baccin, C.; Haas, S. Single-cell and spatial transcriptomics approaches of the bone marrow microenvironment. Curr. Opin. Oncol. 2019, 32, 146-153. [CrossRef]

43. Zilionis, R.; Engblom, C.; Pfirschke, C.; Savova, V.; Zemmour, D.; Saatcioglu, H.D.; Krishnan, I.; Maroni, G.; Meyerovitz, C.V.; Kerwin, C.M.; et al. Single-Cell Transcriptomics of Human and Mouse Lung Cancers Reveals Conserved Myeloid Populations across Individuals and Species. Immunity 2019, 50, 1317-1334. [CrossRef] [PubMed]

44. Yang, L.; George, J.; Wang, J. Deep Profiling of Cellular Heterogeneity by Emerging Single-Cell Proteomic Technologies. Proteomics 2019, 1900226. [CrossRef] [PubMed]

45. Kalb, D.M.; Adikari, S.H.; Hong-Geller, E.; Werner, J.H. Single-cell correlations of mRNA and protein content in a human monocytic cell line after LPS stimulation. PLoS ONE 2019, 14, e0215602. [CrossRef] [PubMed]

46. Luecken, M.D.; Theis, F.J. Current best practices in single-cell RNA-seq analysis: A tutorial. Mol. Syst. Biol. 2019, 15, e8746. [CrossRef] [PubMed]

47. Bartoschek, M.; Oskolkov, N.; Bocci, M.; Lovrot, J.; Larsson, C.; Sommarin, M.; Madsen, C.D.; Lindgren, D.; Pekar, G.; Karlsson, G.; et al. Spatially and functionally distinct subclasses of breast cancer-associated fibroblasts revealed by single cell RNA sequencing. Nat. Commun. 2018, 9, 5150. [CrossRef] [PubMed]

48. Cohen, M.; Giladi, A.; Gorki, A.-D.; Solodkin, D.G.; Zada, M.; Hladik, A.; Miklosi, A.; Salame, T.-M.; Halpern, K.B.; David, E.; et al. Lung Single-Cell Signaling Interaction Map Reveals Basophil Role in Macrophage Imprinting. Cell 2018, 175, 1031-1044. [CrossRef]

49. Neal, J.T.; Li, X.; Zhu, J.; Giangarra, V.; Grzeskowiak, C.L.; Ju, J.; Liu, I.H.; Chiou, S.-H.; Salahudeen, A.A.; Smith, A.R.; et al. Organoid Modeling of the Tumor Immune Microenvironment. Cell 2018, 175, 1972-1988. [CrossRef]

50. Mistry, A.M.; Greenplate, A.R.; Ihrie, R.A.; Irish, J.M. Beyond the message: Advantages of snapshot proteomics with single-cell mass cytometry in solid tumors. FEBS J. 2019, 286, 1523-1539. [CrossRef]

51. Lundberg, E.; Borner, G.H.H. Spatial proteomics: A powerful discovery tool for cell biology. Nat. Rev. Mol. Cell Biol. 2019, 20, 285-302. [CrossRef]

52. Liu, Y.; Chen, X.; Zhang, Y.; Liu, J. Advancing single-cell proteomics and metabolomics with microfluidic technologies. Analyst 2019, 144, 846-858. [CrossRef]

53. Misra, B.B. Open-Source Software Tools, Databases, and Resources for Single-Cell and Single-Cell-Type Metabolomics. Methods Mol. Biol. 2020, 2064, 191-217. [CrossRef] [PubMed]

54. Gilmore, I.S.; Heiles, S.; Pieterse, C.L. Metabolic Imaging at the Single-Cell Scale: Recent Advances in Mass Spectrometry Imaging. In Annual Review of Analytical Chemistry; Bohn, P.W., Pemberton, J.E., Eds.; Annual Reviews: Palo Alto, CA, USA, 2019; Volume 12, pp. 201-224.

55. Ali, A.; Abouleila, Y.; Shimizu, Y.; Hiyama, E.; Emara, S.; Mashaghi, A.; Hankemeier, T. Single-cell metabolomics by mass spectrometry: Advances, challenges, and future applications. TrAC-Trends Anal. Chem. 2019, 120, 115436. [CrossRef] 
56. Thiele, C.; Wunderling, K.; Leyendecker, P. Multiplexed and single cell tracing of lipid metabolism. Nat. Methods 2019, 16, 1123-1130. [CrossRef] [PubMed]

57. Neumann, E.K.; Ellis, J.F.; Triplett, A.E.; Rubakhin, S.S.; Sweedler, J.V. Lipid Analysis of 30000 Individual Rodent Cerebellar Cells Using High-Resolution Mass Spectrometry. Anal. Chem. 2019, 91, 7871-7878. [CrossRef] [PubMed]

58. Zhu, C.; Li, M.; Vincent, T.; Martin, H.L.; Crouch, B.T.; Martinez, A.F.; Madonna, M.C.; Palmer, G.M.; Dewhirst, M.W.; Ramanujam, N. Simultaneous in vivo optical quantification of key metabolic and vascular endpoints reveals tumor metabolic diversity in murine breast tumor models. J. Biophotonics 2019, 12, e201800372. [CrossRef] [PubMed]

59. Madonna, M.C.; Fox, D.B.; Crouch, B.T.; Lee, J.; Zhu, C.; Martinez, A.F.; Alvarez, J.V.; Ramanujam, N. Optical Imaging of Glucose Uptake and Mitochondrial Membrane Potential to Characterize Her2 Breast Tumor Metabolic Phenotypes. Mol. Cancer Res. 2019, 17, 1545-1555. [CrossRef]

60. Zhu, C.; Martin, H.L.; Crouch, B.T.; Martinez, A.F.; Li, M.; Palmer, G.M.; Dewhirst, M.W.; Ramanujam, N. Near-simultaneous quantification of glucose uptake, mitochondrial membrane potential, and vascular parameters in murine flank tumors using quantitative diffuse reflectance and fluorescence spectroscopy. Biomed. Opt. Express 2018, 9, 3399-3412. [CrossRef]

61. Walsh, A.J.; Cook, R.S.; Sanders, M.E.; Aurisicchio, L.; Ciliberto, G.; Arteaga, C.L.; Skala, M.C. Quantitative Optical Imaging of Primary Tumor Organoid Metabolism Predicts Drug Response in Breast Cancer. Cancer Res. 2014, 74, 5184-5194. [CrossRef]

62. Rak, J. Microparticles in Cancer. Semin. Thromb. Hemost. 2010, 36, 888-906. [CrossRef]

63. Beloribi-Djefaflia, S.; Siret, C.; Lombardo, D. Exosomal lipids induce human pancreatic tumoral MiaPaCa-2 cells resistance through the CXCR4-SDF-1alpha signaling axis. Oncoscience 2015, 2, 15-30. [CrossRef]

64. Decalf, J.; Albert, M.L.; Ziai, J. New tools for pathology: A user's review of a highly multiplexed method for in situ analysis of protein and RNA expression in tissue. J. Pathol. 2019, 247, 650-661. [CrossRef] [PubMed]

65. Johnson, D.B.; McDonnell, W.J.; Gonzalez-Ericsson, P.I.; Al-Rohil, R.N.; Mobley, B.C.; Salem, J.E.; Wang, D.Y.; Sanchez, V.; Wang, Y.; Chastain, C.A.; et al. A case report of clonal EBV-like memory CD4(+) T cell activation in fatal checkpoint inhibitor-induced encephalitis. Nat. Med. 2019, 25, 1243-1250. [CrossRef] [PubMed]

66. Toki, M.I.; Merritt, C.R.; Wong, P.F.; Smithy, J.W.; Kluger, H.M.; Syrigos, K.N.; Ong, G.T.; Warren, S.E.; Beechem, J.M.; Rimm, D.L. High-Plex Predictive Marker Discovery for Melanoma Immunotherapy-Treated Patients Using Digital Spatial Profiling. Clin. Cancer Res. 2019, 25, 5503-5512. [CrossRef] [PubMed]

67. Davis-Marcisak, E.F.; Sherman, T.D.; Orugunta, P.; Stein-O’Brien, G.L.; Puram, S.V.; Torres, E.T.R.; Hopkins, A.C.; Jaffee, E.M.; Favorov, A.V.; Afsari, B.; et al. Differential Variation Analysis Enables Detection of Tumor Heterogeneity Using Single-Cell RNA-Sequencing Data. Cancer Res. 2019, 79, 5102-5112. [CrossRef] [PubMed]

68. Eberwine, J.; Sul, J.-Y.; Bartfai, T.; Kim, J. The promise of single-cell sequencing. Nat. Methods 2014, 11, 25-27. [CrossRef]

69. Savas, P.; Virassamy, B.; Ye, C.; Salim, A.; Mintoff, C.P.; Caramia, F.; Salgado, R.; Byrne, D.J.; Teo, Z.L.; Dushyanthen, S.; et al. Single-cell profiling of breast cancer T cells reveals a tissue-resident memory subset associated with improved prognosis. Nat. Med. 2018, 24, 986-993. [CrossRef]

70. Perl, K.; Ushakov, K.; Pozniak, Y.; Yizhar-Barnea, O.; Bhonker, Y.; Shivatzki, S.; Geiger, T.; Avraham, K.B.; Shamir, R. Reduced changes in protein compared to mRNA levels across non-proliferating tissues. BMC Genom. 2017, 18, 305. [CrossRef]

71. Liu, Y.; Beyer, A.; Aebersold, R. On the Dependency of Cellular Protein Levels on mRNA Abundance. Cell 2016, 165, 535-550. [CrossRef]

72. Edfors, F.; Danielsson, F.; Hallstrom, B.M.; Kall, L.; Lundberg, E.; Ponten, F.; Forsstrom, B.; Uhlen, M. Gene-specific correlation of RNA and protein levels in human cells and tissues. Mol. Syst. Biol. 2016, $12,883$. [CrossRef]

73. Vogel, C.; Marcotte, E.M. Insights into the regulation of protein abundance from proteomic and transcriptomic analyses. Nat. Rev. Genet. 2012, 13, 227-232. [CrossRef]

74. Brahimi-Horn, M.C.; Pouyssegur, J. Hypoxia in cancer cell metabolism and pH regulation. Essays Biochem. 2007, 43, 165-178. [CrossRef] [PubMed]

75. Fukumura, D.; Jain, R.K. Tumor microvasculature and microenvironment: Targets for anti-angiogenesis and normalization. Microvasc. Res. 2007, 74, 72-84. [CrossRef] [PubMed] 
76. Giussani, M.; Merlino, G.; Cappelletti, V.; Tagliabue, E.; Daidone, M.G. Tumor-extracellular matrix interactions: Identification of tools associated with breast cancer progression. Semin. Cancer Biol. 2015, 35, 3-10. [CrossRef] [PubMed]

77. Fan, T.W.M.; El-Amouri, S.S.; Macedo, J.K.A.; Wang, Q.J.; Song, H.; Cassel, T.; Lane, A.N. Stable Isotope-Resolved Metabolomics Shows Metabolic Resistance to Anti-Cancer Selenite in 3D Spheroids versus 2D Cell Cultures. Metabolites 2018, 8, 40. [CrossRef] [PubMed]

78. Jiang, L.; Shestov, A.A.; Swain, P.; Yang, C.; Parker, S.J.; Wang, Q.A.; Terada, L.S.; Adams, N.D.; McCabe, M.T.; Pietrak, B.; et al. Reductive carboxylation supports redox homeostasis during anchorage-independent growth. Nature 2016, 532, 255-258. [CrossRef]

79. Lane, A.N.; Higashi, R.M.; Fan, T.W.-M. Metabolic reprogramming in tumors: Contributions of the tumor microenvironment. Genes Dis. 2019, 7, 185-198. [CrossRef]

80. Zhang, L.; Zheng, J.; Ahmed, R.; Huang, G.; Reid, J.; Mandal, R.; Maksymuik, A.; Sitar, D.S.; Tappia, P.S.; Ramjiawan, B.; et al. A High-Performing Plasma Metabolite Panel for Early-Stage Lung Cancer Detection. Cancers 2020, 12, 622. [CrossRef]

81. Schmidt, J.A.; Fensom, G.K.; Rinaldi, S.; Scalbert, A.; Appleby, P.N.; Achaintre, D.; Gicquiau, A.; Gunter, M.J.; Ferrari, P.; Kaaks, R.; et al. Patterns in metabolite profile are associated with risk of more aggressive prostate cancer: A prospective study of 3,057 matched case-control sets from EPIC. Int. J. Cancer 2020, 146, 720-730. [CrossRef]

82. His, M.; Viallon, V.; Dossus, L.; Gicquiau, A.; Achaintre, D.; Scalbert, A.; Ferrari, P.; Romieu, I.; Onland-Moret, N.C.; Weiderpass, E.; et al. Prospective analysis of circulating metabolites and breast cancer in EPIC. BMC Med. 2019, 17, 178. [CrossRef]

83. Fan, T.W.M.; Zhang, X.; Wang, C.; Yang, Y.; Kang, W.-Y.; Arnold, S.; Higashi, R.M.; Liu, J.; Lane, A.N. Exosomal lipids for classifying early and late stage non-small cell lung cancer. Anal. Chim. Acta 2018, 1037, 256-264. [CrossRef]

84. Martin, J.C.; Maillot, M.; Mazerolles, G.; Verdu, A.; Lyan, B.; Migne, C.; Defoort, C.; Canlet, C.; Junot, C.; Guillou, C.; et al. Can we trust untargeted metabolomics? Results of the metabo-ring initiative, a large-scale, multi-instrument inter-laboratory study. Metabolomics 2015, 11, 807-821. [CrossRef] [PubMed]

85. Deda, O.; Virgiliou, C.; Orfanidis, A.; Gika, H.G. Study of Fecal and Urinary Metabolite Perturbations Induced by Chronic Ethanol Treatment in Mice by UHPLC-MS/MS Targeted Profiling. Metabolites 2019, 9, 232. [CrossRef] [PubMed]

86. Want, E.J.; Wilson, I.D.; Gika, H.; Theodoridis, G.; Plumb, R.S.; Shockcor, J.; Holmes, E.; Nicholson, J.K. Global metabolic profiling procedures for urine using UPLC-MS. Nat. Protoc. 2010, 5, 1005-1018. [CrossRef] [PubMed]

87. Ballester, L.Y.; Lu, G.; Zorofchian, S.; Vantaku, V.; Putluri, V.; Yan, Y.; Arevalo, O.; Zhu, P.; Riascos, R.F.; Sreekumar, A.; et al. Analysis of cerebrospinal fluid metabolites in patients with primary or metastatic central nervous system tumors. Acta Neuropathol. Commun. 2018, 6, 85. [CrossRef] [PubMed]

88. Yoo, B.C.; Lee, J.H.; Kim, K.-H.; Lin, W.; Kim, J.H.; Park, J.B.; Park, H.J.; Shin, S.H.; Yoo, H.; Kwon, J.W.; et al. Cerebrospinal fluid metabolomic profiles can discriminate patients with leptomeningeal carcinomatosis from patients at high risk for leptomeningeal metastasis. Oncotarget 2017, 8, 101203-101214. [CrossRef]

89. Vignoli, A.; Paciotti, S.; Tenori, L.; Eusebi, P.; Biscetti, L.; Chiasserini, D.; Scheltens, P.; Turano, P.; Teunissen, C.; Luchinat, C.; et al. Fingerprinting Alzheimer's Disease by $1 \mathrm{H}$ Nuclear Magnetic Resonance Spectroscopy of Cerebrospinal Fluid. J. Proteome Res. 2020, 19, 1696-1705. [CrossRef]

90. Fan, T.W.; Lane, A.N.; Higashi, R.M.; Farag, M.A.; Gao, H.; Bousamra, M.; Miller, D.M. Altered regulation of metabolic pathways in human lung cancer discerned by (13)C stable isotope-resolved metabolomics (SIRM). Mol. Cancer 2009, 8, 41. [CrossRef]

91. Sellers, K.; Fox, M.P.; Bousamra, M., 2nd; Slone, S.P.; Higashi, R.M.; Miller, D.M.; Wang, Y.; Yan, J.; Yuneva, M.O.; Deshpande, R.; et al. Pyruvate carboxylase is critical for non-small-cell lung cancer proliferation. J. Clin. Investig. 2015, 125, 687-698. [CrossRef]

92. Bruntz, R.C.; Higashi, R.M.; Lane, A.N.; Fan, T.W.-M. Exploring Cancer Metabolism using Stable Isotope Resolved Metabolomics (SIRM). J. Biol. Chem. 2017, 292, 11601-11609. [CrossRef]

93. Rao, T.N.; Hansen, N.; Hilfiker, J.; Rai, S.; Majewska, J.-M.; Lekovic, D.; Gezer, D.; Andina, N.; Galli, S.; Cassel, T.; et al. JAK2-mutant hematopoietic cells display metabolic alterations that can be targeted to treat myeloproliferative neoplasms. Blood 2019, 134, 1832-1846. [CrossRef] 
94. Malloy, C.R.; Maher, E.; Marin-Valenica, I.; Mickey, B.; DeBerardinis, R.J.; Sherry, A.D. Carbon-13 Nuclear Magnetic Resonance for Analysis of Metabolc Pathways. In Methodologies for Metabolomics: Experimental Strategies and Techniques; Lutz, N., Sweedler, J.V., Weevers, R.A., Eds.; Cambridge University Press: Cambridge, UK, 2013; pp. 415-445.

95. Winnike, J.H.; Pediaditakis, P.; Wolak, J.E.; McClelland, R.W.; Watkins, P.B.; Macdonald, J.M. Stable isotope resolved metabolomics of primary human hepatocytes reveals a stressed phenotype. Metabolomics 2012, 8 , 34-49. [CrossRef]

96. Liu, X.; Cooper, D.E.; Cluntun, A.A.; Warmoes, M.O.; Zhao, S.; Reid, M.A.; Liu, J.; Lund, P.J.; Lopes, M.; Garcia, B.A.; et al. Acetate Production from Glucose and Coupling to Mitochondrial Metabolism in Mammals. Cell 2018, 175, 502-513. [CrossRef]

97. Lane, A.N.; Higashi, R.M.; Fan, T.W.M. NMR and MS-based Stable Isotope-Resolved Metabolomics and applications in cancer metabolism. TrAC-Trends Anal. Chem. 2019, 120, 115322. [CrossRef] [PubMed]

98. Niedenfuhr, S.; Wiechert, W.; Noh, K. How to measure metabolic fluxes: A taxonomic guide for (13)C fluxomics. Curr. Opin. Biotechnol. 2015, 34, 82-90. [CrossRef] [PubMed]

99. Wiechert, W.; Noh, K. Isotopically non-stationary metabolic flux analysis: Complex yet highly informative. Curr. Opin. Biotechnol. 2013, 24, 979-986. [CrossRef] [PubMed]

100. Murphy, T.A.; Dang, C.V.; Young, J.D. Isotopically nonstationary $13 \mathrm{C}$ flux analysis of Myc-induced metabolic reprogramming in B-cells. Metab. Eng. 2013, 15, 206-217. [CrossRef]

101. Fan, T.W.-M.; Bandura, L.; Higashi, R.M.; Lane, A.N. Metabolomics-edited transcriptomics analysis of Se anticancer action in human lung cancer cells. Metabolomics 2005, 1, 325-339. [CrossRef]

102. Fan, T.W.-M.; Lane, A.N.; Higashi, R.M.; Yan, J. Stable Isotope Resolved Metabolomics of Lung Cancer in a SCID Mouse Model. Metabolomics 2011, 7, 257-269. [CrossRef]

103. Fan, T.W.-M.; Tan, J.L.; McKinney, M.M.; Lane, A.N. Stable Isotope Resolved Metabolomics Analysis of Ribonucleotide and RNA Metabolism in Human Lung Cancer Cells. Metabolomics 2012, 8, 517-527. [CrossRef]

104. Ren, J.G.; Seth, P.; Clish, C.B.; Lorkiewicz, P.K.; Higashi, R.M.; Lane, A.N.; Fan, T.W.M.; Sukhatme, V.P. Knockdown of Malic Enzyme 2 Suppresses Lung Tumor Growth, Induces Differentiation and Impacts PI3K/AKT Signaling. Sci. Rep. 2014, 4, 5414. [CrossRef]

105. Xie, H.; Hanai, J.; Ren, J.-G.; Kats, L.; Burgess, K.; Bhargava, P.; Signoretti, S.; Billiard, J.; Duffy, K.J.; Grant, A.; et al. Targeting lactate dehydrogenase-A (LDH-A) inhibits tumorigenesis and tumor progression in mouse models of lung cancer and impacts tumor initiating cells. Cell Metab. 2014, 19, 795-809. [CrossRef] [PubMed]

106. Sun, R.C.; Fan, T.W.-M.; Deng, P.; Higashi, R.M.; Lane, A.N.; Le, A.-T.; Scott, T.J.; Sun, Q.; Warmoes, M.O.; Yang, Y. Noninvasive liquid diet delivery of stable isotopes into mouse models for deep metabolic network tracing. Nat. Commun. 2017, 8, 1646. [CrossRef] [PubMed]

107. Fan, T.W.-M.; Bruntz, R.C.; Yang, Y.; Song, H.; Chernyavskaya, Y.; Deng, P.; Zhang., Y.; Shah, P.P.; Beverly, L.J.; Chi, Z.; et al. De novo synthesis of serine and glycine fuels purine nucleotide biosynthesis in human lung cancer tissues. J. Biol. Chem. 2019, 294, 13464-13477. [CrossRef] [PubMed]

108. Lane, A.N.; Higashi, R.M.; Fan, T.W.-M. Preclinical models for interrogating drug action in human cancers using Stable Isotope Resolved Metabolomics (SIRM). Metabolomics 2016, 12, 1-15. [CrossRef]

109. Edmondson, R.; Broglie, J.J.; Adcock, A.F.; Yang, L. Three-Dimensional Cell Culture Systems and Their Applications in Drug Discovery and Cell-Based Biosensors. Assay Drug Dev. Technol. 2014, 12, $207-218$. [CrossRef]

110. Hay, M.; Thomas, D.W.; Craighead, J.L.; Economides, C.; Rosenthal, J. Clinical development success rates for investigational drugs. Nat. Biotechnol. 2014, 32, 40-51. [CrossRef]

111. Kapałczyńska, M.; Kolenda, T.; Przybyła, W.; Zajączkowska, M.; Teresiak, A.; Filas, V.; Ibbs, M.; Bliźniak, R.; Łuczewski, Ł.; Lamperska, K. 2D and 3D cell cultures - a comparison of different types of cancer cell cultures. Arch. Med. Sci. 2018, 14, 910-919.

112. Langhans, S. Three-Dimensional in Vitro Cell Culture Models in Drug Discovery and Drug Repositioning. Front. Pharmacol. 2018, 9, 6. [CrossRef]

113. Farge, T.; Saland, E.; de Toni, F.; Aroua, N.; Hosseini, M.; Perry, R.; Bosc, C.; Sugita, M.; Stuani, L.; Fraisse, M.; et al. Chemotherapy-Resistant Human Acute Myeloid Leukemia Cells Are Not Enriched for Leukemic Stem Cells but Require Oxidative Metabolism. Cancer Discov. 2017, 7, 716-735. [CrossRef] 
114. Maykel, J.; Liu, J.H.; Li, H.; Shultz, L.D.; Greiner, D.L.; Houghton, J. NOD-scidIl2rg (tm1Wjl) and NOD-Rag1 (null) Il2rg (tm1Wjl): A model for stromal cell-tumor cell interaction for human colon cancer. Dig. Dis. Sci. 2014, 59, 1169-1179. [CrossRef]

115. Whittle, J.R.; Lewis, M.T.; Lindeman, G.J.; Visvader, J.E. Patient-derived xenograft models of breast cancer and their predictive power. Breast Cancer Res. 2015, 17, 17. [CrossRef]

116. Lee, G.Y.; Kenny, P.A.; Lee, E.H.; Bissell, M.J. Three-dimensional culture models of normal and malignant breast epithelial cells. Nat. Methods 2007, 4, 359-365. [CrossRef] [PubMed]

117. Radisky, D.C.; Bissell, M.J. Respect thy neighbor! Science 2004, 303, 775-777. [CrossRef] [PubMed]

118. Bissell, M.J.; Rizki, A.; Mian, I.S. Tissue architecture: The ultimate regulator of breast epithelial function. Curr. Opin. Cell Biol. 2003, 15, 753-762. [CrossRef] [PubMed]

119. Holokai, L.; Chakrabarti, J.; Broda, T.; Chang, J.; Hawkins, J.A.; Sundaram, N.; Wroblewski, L.E.; Peek, R.M., Jr.; Wang, J.; Helmrath, M.; et al. Increased Programmed Death-Ligand 1 is an Early Epithelial Cell Response to Helicobacter pylori Infection. PLoS Pathog. 2019, 15, e1007648. [CrossRef] [PubMed]

120. Takebe, T.; Wells, J.M. Organoids by design. Science 2019, 364, 956-959. [CrossRef]

121. Fan, T.W.-M.; El-Amouri, S.S.; Macedo, J.K.A.; Wang, Q.J.; Cassel, T.A.; Lane, A.N. Mapping Metabolic Networks in 3D Spheroids Using Stable Isotope-Resolved Metabolomics. In Proceedings of the 2nd International Electronic Conference on Metabolomics, Melbourne, Australia, 20-27 November 2017.

122. Tseng, H.; Gage, J.A.; Shen, T.; Haisler, W.L.; Neeley, S.K.; Shiao, S.; Chen, J.; Desai, P.K.; Liao, A.; Hebel, C.; et al. A spheroid toxicity assay using magnetic 3D bioprinting and real-time mobile device-based imaging. Sci. Rep. 2015, 5, 13987. [CrossRef]

123. Tsukikawa, S.; Matsuoka, H.; Kurahashi, Y.; Konno, Y.; Satoh, K.; Satoh, R.; Isogai, A.; Kimura, K.; Watanabe, Y.; Nakano, S.; et al. A new method to prepare multicellular spheroids in cancer cell lines using a thermo-reversible gelation polymer. Artif. Organs 2003, 27, 598-604. [CrossRef]

124. Wehrle, J.P.; Ng, C.E.; McGovern, K.A.; Aiken, N.R.; Shungu, D.C.; Chance, E.M.; Glickson, J.D. Metabolism of alternative substrates and the bioenergetic status of EMT6 tumor cell spheroids. NMR Biomed. 2000, 13, 349-360. [CrossRef]

125. Pawlik, T.M.; Souba, W.W.; Sweeney, T.J.; Bode, B.P. Amino acid uptake and regulation in multicellular hepatoma spheroids. J. Surg. Res. 2000, 91, 15-25. [CrossRef]

126. Nath, S.; Devi, G.R. Three-dimensional culture systems in Cancer research: Focus on tumor spheroid model. Pharmacol. Ther. 2016, 163, 94-108. [CrossRef] [PubMed]

127. Marrella, A.; Dondero, A.; Aiello, M.; Casu, B.; Olive, D.; Regis, S.; Bottino, C.; Pende, D.; Meazza, R.; Caluori, G.; et al. Cell-Laden Hydrogel as a Clinical-Relevant 3D Model for Analyzing Neuroblastoma Growth, Immunophenotype, and Susceptibility to Therapies. Front. Immunol. 2019, 10, 1876. [CrossRef] [PubMed]

128. Cavo, M.; Caria, M.; Pulsoni, I.; Beltrame, F.; Fato, M.; Scaglione, S. A new cell-laden 3D Alginate-Matrigel hydrogel resembles human breast cancer cell malignant morphology, spread and invasion capability observed "in vivo". Sci. Rep. 2018, 8, 5333. [CrossRef] [PubMed]

129. Hassani, F.; Ebrahimi, B.; Moini, A.; Ghiaseddin, A.; Bazrafkan, M.; Hassanzadeh, G.; Valojerdi, M.R. Chitosan Hydrogel Supports Integrity of Ovarian Follicles during In Vitro Culture: A Preliminary of A Novel Biomaterial for Three Dimensional Culture of Ovarian Follicles. Cell J. 2020, 21, 479-493. [CrossRef] [PubMed]

130. Jiang, J.-P.; Liu, X.-Y.; Zhao, F.; Zhu, X.; Li, X.-Y.; Niu, X.-G.; Yao, Z.-T.; Dai, C.; Xu, H.-Y.; Ma, K.; et al. Three-dimensional bioprinting collagen/silk fibroin scaffold combined with neural stem cells promotes nerve regeneration after spinal cord injury. Neural Regen. Res. 2020, 15, 959-968. [CrossRef] [PubMed]

131. Kruger, M.; Oosterhoff, L.A.; van Wolferen, M.E.; Schiele, S.A.; Walther, A.; Geijsen, N.; De Laporte, L.; van der Laan, L.J.W.; Kock, L.M.; Spee, B. Cellulose Nanofibril Hydrogel Promotes Hepatic Differentiation of Human Liver Organoids. Adv. Healthc. Mater. 2020, 9, 1901658. [CrossRef] [PubMed]

132. Oliveira, N.M.; Martins-Cruz, C.; Oliveira, M.B.; Reis, R.L.; Mano, J.F. Coculture of Spheroids/2D Cell Layers Using a Miniaturized Patterned Platform as a Versatile Method to Produce Scaffold-Free Tissue Engineering Building Blocks. Adv. Biosyst. 2018, 2, 17800069. [CrossRef]

133. Vives, J.; Batlle-Morera, L. The challenge of developing human 3D organoids into medicines. Stem Cell Res. Ther. 2020, 11. [CrossRef] 
134. Yoshioka, K.; Ito, A.; Kawabe, Y.; Kamihira, M. Novel neuromuscular junction model in 2D and 3D myotubes co-cultured with induced pluripotent stem cell-derived motor neurons. J. Biosci. Bioeng. 2020, 129, 486-493. [CrossRef]

135. Augustine, T.N.; Dix-Peek, T.; Duarte, R.; Candy, G.P. Establishment of a heterotypic 3D culture system to evaluate the interaction of TREG lymphocytes and NK cells with breast cancer. J. Immunol. Methods 2015, 426, 1-13. [CrossRef]

136. Maritan, S.M.; Lian, E.Y.; Mulligan, L.M. An Efficient and Flexible Cell Aggregation Method for 3D Spheroid Production. J. Vis. Exp. 2017, 121, e55544. [CrossRef] [PubMed]

137. Sant, S.; Johnston, P. The production of 3D tumor spheroids for cancer drug discovery. Drug Discov. Today: Technol. 2017, 23, 27-36. [CrossRef] [PubMed]

138. Djomehri, S.I.; Burman, B.; Gonzalez, M.E.; Takayama, S.; Kleer, C.G. A reproducible scaffold-free 3D organoid model to study neoplastic progression in breast cancer. J. Cell Commun. Signal. 2019, 13, 129-143. [CrossRef] [PubMed]

139. Eder, T.; Eder, I.E. 3D Hanging Drop Culture to Establish Prostate Cancer Organoids. In $3 d$ Cell Culture: Methods and Protocols; Koledova, Z., Ed.; Springer: Berlin, Germany, 2017; Volume 1612, pp. 167-175.

140. Workman, M.J.; Mahe, M.M.; Trisno, S.; Poling, H.M.; Watson, C.L.; Sundaram, N.; Chang, C.-F.; Schiesser, J.; Aubert, P.; Stanley, E.G.; et al. Engineered human pluripotent-stem-cell-derived intestinal tissues with a functional enteric nervous system. Nat. Med. 2017, 23, 49-59. [CrossRef] [PubMed]

141. Arnadottir, S.S.; Jeppesen, M.; Lamy, P.; Bramsen, J.B.; Nordentoft, I.; Knudsen, M.; Vang, S.; Madsen, M.R.; Thastrup, O.; Thastrup, J.; et al. Characterization of genetic intratumor heterogeneity in colorectal cancer and matching patient-derived spheroid cultures. Mol. Oncol. 2018, 12, 132-147. [CrossRef]

142. Bejoy, J.; Yuan, X.G.; Song, L.Q.; Hua, E.; Jeske, R.; Sart, S.; Sang, Q.X.A.; Li, Y. Genomics Analysis of Metabolic Pathways of Human Stem Cell-Derived Microglia-Like Cells and the Integrated Cortical Spheroids. Stem Cells Int. 2019, 2019, 2382534. [CrossRef]

143. Bhagwat, S.R.; Chandrashekar, D.S.; Kakar, R.; Davuluri, S.; Bajpai, A.K.; Nayak, S.; Bhutada, S.; Acharya, K.; Sachdeva, G. Endometrial Receptivity: A Revisit to Functional Genomics Studies on Human Endometrium and Creation of HGEx-ERdb. PLoS ONE 2013, 8, e58419. [CrossRef]

144. Eckert, M.A.; Pan, S.; Hernandez, K.M.; Loth, R.M.; Andrade, J.; Volchenboum, S.L.; Faber, P.; Montag, A.; Lastra, R.; Peter, M.E.; et al. Genomics of Ovarian Cancer Progression Reveals Diverse Metastatic Trajectories Including Intraepithelial Metastasis to the Fallopian Tube. Cancer Discov. 2016, 6, 1342-1351. [CrossRef]

145. Horman, S.R.; Hogan, C.; Delos Reyes, K.; Lo, F.; Antczak, C. Challenges and opportunities toward enabling phenotypic screening of complex and 3D cell models. Future Med. Chem. 2015, 7, 513-525. [CrossRef]

146. Morrison, E.; Wai, P.; Leonidou, A.; Bland, P.; Khalique, S.; Farnie, G.; Daley, F.; Peck, B.; Natrajan, R. Utilizing Functional Genomics Screening to Identify Potentially Novel Drug Targets in Cancer Cell Spheroid Cultures. J. Vis. Exp. 2016, 118, 54738. [CrossRef]

147. Nowack, E.C.M.; Weber, A.P.M. Genomics-Informed Insights into Endosymbiotic Organelle Evolution in Photosynthetic Eukaryotes. In Annual Review of Plant Biology; Merchant, S.S., Ed.; Annual Reviews: Palo Alto, CA, USA, 2018; Volume 69, pp. 51-84.

148. Powell, C.D.; Paullin, T.R.; Aoisa, C.; Menzie, C.J.; Ubaldini, A.; Westerheide, S.D. The Heat Shock Transcription Factor HSF1 Induces Ovarian Cancer Epithelial-Mesenchymal Transition in a 3D Spheroid Growth Model. PLoS ONE 2016, 11, e0168389. [CrossRef] [PubMed]

149. Alfoldi, R.; Balog, J.A.; Farago, N.; Halmai, M.; Kotogany, E.; Neuperger, P.; Nagy, L.I.; Feher, L.Z.; Szebeni, G.J.; Puskas, L.G. Single Cell Mass Cytometry of Non-Small Cell Lung Cancer Cells Reveals Complexity of In Vivo and Three-Dimensional Models over the Petri-Dish. Cells 2019, 8, 1093. [CrossRef] [PubMed]

150. Chumarina, M.; Russ, K.; Azevedo, C.; Heuer, A.; Pihl, M.; Collin, A.; Frostner, E.A.; Elmer, E.; Hyttel, P.; Cappelletti, G.; et al. Cellular alterations identified in pluripotent stem cell-derived midbrain spheroids generated from a female patient with progressive external ophthalmoplegia and parkinsonism who carries a novel variation (p.Q811R) in the POLG1 gene. Acta Neuropathol. Commun. 2019, 7, 208. [CrossRef]

151. Ayerim Mandujano-Tinoco, E.; Carlos Gallardo-Perez, J.; Marin-Hernandez, A.; Moreno-Sanchez, R.; Rodriguez-Enriquez, S. Anti-mitochondrial therapy in human breast cancer multi-cellular spheroids. Biochim. Biophys. Acta-Mol. Cell Res. 2013, 1833, 541-551. [CrossRef] [PubMed]

152. Desai, P.K.; Tseng, H.; Souza, G.R. Assembly of Hepatocyte Spheroids Using Magnetic 3D Cell Culture for CYP450 Inhibition/Induction. Int. J. Mol. Sci. 2017, 18, 1085. [CrossRef] 
153. Kalfe, A.; Telfah, A.; Lambert, J.; Hergenroeder, R. Looking into Living Cell Systems: Planar Waveguide Microfluidic NMR Detector for in Vitro Metabolomics of Tumor Spheroids. Anal. Chem. 2015, 87, 7402-7410. [CrossRef]

154. Kozyra, M.; Johansson, I.; Nordling, A.; Ullah, S.; Lauschke, V.M.; Ingelman-Sundberg, M. Human hepatic 3D spheroids as a model for steatosis and insulin resistance. Sci. Rep. 2018, 8, 14297. [CrossRef]

155. Lee, J.; Kee, H.J.; Min, S.; Park, K.C.; Park, S.; Hwang, T.H.; Ryu, D.H.; Hwang, G.-S.; Cheong, J.-H. Integrated omics-analysis reveals Wnt-mediated $\mathrm{NAD}(+)$ metabolic reprogramming in cancer stem-like cells. Oncotarget 2016, 7, 48562-48576. [CrossRef]

156. Loverdou, N.; Hall, G.N.; Papantoniou, I.; Geris, L. Metabolomics as a quality control tool for spheroid-based chondrogenic differentiation-towards characterized endochondral bone regeneration. Cytotherapy 2018, 20, S67. [CrossRef]

157. Michishita, M.; Saito, N.; Nozawa, S.; Furumoto, R.; Nakagawa, T.; Sato, T.; Ochiai, K.; Azakami, D.; Katayama, K.; Nakahira, R.; et al. Metabolite profiling in sphere-forming cells from canine mammary adenocarcinoma cell lines using gas chromatography-mass spectrometry. J. Vet. Med. Sci. 2019, 81, 1238-1248. [CrossRef]

158. Okkelman, I.A.; Neto, N.; Papkovsky, D.B.; Monaghan, M.G.; Dmitriev, R.I. A deeper understanding of intestinal organoid metabolism revealed by combining fluorescence lifetime imaging microscopy (FLIM) and extracellular flux analyses. Redox Biol. 2020, 30, 101420. [CrossRef] [PubMed]

159. Russell, S.; Wojtkowiak, J.; Neilson, A.; Gillies, R.J. Metabolic Profiling of healthy and cancerous tissues in 2D and 3D. Sci. Rep. 2017, 7, 15285. [CrossRef] [PubMed]

160. Sato, M.; Kawana, K.; Adachi, K.; Fujimoto, A.; Yoshida, M.; Nakamura, H.; Nishida, H.; Inoue, T.; Taguchi, A.; Takahashi, J.; et al. Spheroid cancer stem cells display reprogrammed metabolism and obtain energy by actively running the tricarboxylic acid (TCA) cycle. Oncotarget 2016, 7, 33297-33305. [CrossRef] [PubMed]

161. Tanaka, K.; Matsuura, T.; Nakada, K. Method of Assessment for 3D Reconstructed Bioartificial Liver Using C-13-glucose Breath Test. Radioisotopes 2010, 59, 435-440. [CrossRef]

162. van Gorsel, M.; Elia, I.; Fendt, S.-M. 13C Tracer Analysis and Metabolomics in 3D Cultured Cancer Cells. Methods Mol. Biol. 2019, 1862, 53-66. [CrossRef]

163. Vermeersch, K.A.; Wang, L.; Mezencev, R.; McDonald, J.F.; Styczynski, M.P. OVCAR-3 Spheroid-Derived Cells Display Distinct Metabolic Profiles. PLoS ONE 2015, 10, e0118262. [CrossRef]

164. Vorrink, S.U.; Ullah, S.; Schmidt, S.; Nandania, J.; Velagapudi, V.; Beck, O.; Ingelman-Sundberg, M.; Lauschke, V.M. Endogenous and xenobiotic metabolic stability of primary human hepatocytes in long-term 3D spheroid cultures revealed by a combination of targeted and untargeted metabolomics. FASEB J. 2017, 31, 2696-2708. [CrossRef]

165. Yan, Y.; Bejoy, J.; Marzano, M.; Li, Y. The Use of Pluripotent Stem Cell-Derived Organoids to Study Extracellular Matrix Development during Neural Degeneration. Cells 2019, 8, 242. [CrossRef]

166. Northcutt, L.A.; Suarez-Arnedo, A.; Rafat, M. Emerging Biomimetic Materials for Studying Tumor and Immune Cell Behavior. Ann. Biomed. Eng. 2019. [CrossRef]

167. Kawai, T.; Ota, N.; Okada, K.; Imasato, A.; Owa, Y.; Morita, M.; Tada, M.; Tanaka, Y. Ultrasensitive Single Cell Metabolomics by Capillary Electrophoresis-Mass Spectrometry with a Thin-Walled Tapered Emitter and Large-Volume Dual Sample Preconcentration. Anal. Chem. 2019, 91, 10564-10572. [CrossRef]

168. Lane, A.N. Principles of NMR for applications in metabolomics. In Handbook of Metabolomics; Fan, T.W.-M., Lane, A.N., Higashi, R.M., Eds.; Humana: Louisville, KY, USA, 2012; Volume 17, pp. 127-197.

169. Ardenkjaer-Larsen, J.H.; Fridlund, B.; Gram, A.; Hansson, G.; Hansson, L.; Lerche, M.H.; Servin, R.; Thaning, M.; Golman, K. Increase in signal-to-noise ratio of $>10,000$ times in liquid-state NMR. Proc. Natl. Acad. Sci. USA 2003, 100, 10158-10163. [CrossRef] [PubMed]

170. Yang, Y.; Fan, W.W.-M.; Lane, A.N.; Higashi, R.M. Chloroformate Derivatization for Tracing the Fate of Amino Acids in Cells by Multiple Stable Isotope Resolved Metabolomics (mSIRM). Anal. Chim. Acta 2017, 976, 63-73. [CrossRef]

171. Liu, M.; Luo, F.; Ding, C.; Albeituni, S.; Hu, X.; Ma, Y.; Cai, Y.; McNally, L.; Sanders, M.A.; Jain, D.; et al. Dectin-1 Activation by a Natural Product beta-Glucan Converts Immunosuppressive Macrophages into an M1-like Phenotype. J. Immunol. 2015, 195, 5055-5065. [CrossRef] [PubMed] 
172. Jaguin, M.; Houlbert, N.; Fardel, O.; Lecureur, V. Polarization profiles of human M-CSF-generated macrophages and comparison of M1-markers in classically activated macrophages from GM-CSF and M-CSF origin. Cell. Immunol. 2013, 281, 51-61. [CrossRef] [PubMed]

173. Minhas, P.S.; Liu, L.; Moon, P.K.; Joshi, A.U.; Dove, C.; Mhatre, S.; Contrepois, K.; Wang, Q.; Lee, B.A.; Coronado, M.; et al. Macrophage de novo $\operatorname{NAD}(+)$ synthesis specifies immune function in aging and inflammation. Nat. Immunol. 2019, 20, 50-63. [CrossRef] [PubMed]

174. El Kasmi, K.C.; Stenmark, K.R. Contribution of metabolic reprogramming to macrophage plasticity and function. Semin. Immunol. 2015, 27, 267-275. [CrossRef]

175. O'Neill, L.A. A broken krebs cycle in macrophages. Immunity 2015, 42, 393-394. [CrossRef]

176. Palmieri, E.M.; Gonzalez-Cotto, M.; Baseler, W.A.; Davies, L.C.; Ghesquière, B.; Maio, N.; Rice, C.M.; Rouault, T.A.; Cassel, T.; Higashi, R.M.; et al. Nitric Oxide Orchestrates the Rewiring of Carbon Utilization During M1 Macrophage Polarization. Nat. Commun. 2020, 11, 698. [CrossRef]

177. Nonnenmacher, Y.; Hiller, K. Biochemistry of proinflammatory macrophage activation. Cell Mol. Life Sci. 2018, 75, 2093-2109. [CrossRef]

178. Lampropoulou, V.; Sergushichev, A.; Bambouskova, M.; Nair, S.; Vincent, E.E.; Loginicheva, E.; Cervantes-Barragan, L.; Ma, X.; Huang, S.C.; Griss, T.; et al. Itaconate Links Inhibition of Succinate Dehydrogenase with Macrophage Metabolic Remodeling and Regulation of Inflammation. Cell Metab. 2016, 24, 158-166. [CrossRef]

179. Mills, E.L.; Ryan, D.G.; Prag, H.A.; Dikovskaya, D.; Menon, D.; Zaslona, Z.; Jedrychowski, M.P.; Costa, A.S.H.; Higgins, M.; Hams, E.; et al. Itaconate is an anti-inflammatory metabolite that activates Nrf2 via alkylation of KEAP1. Nature 2018, 556, 113. [CrossRef] [PubMed]

180. Kwon, D.H.; Lee, H.; Park, C.; Hong, S.H.; Hong, S.H.; Kim, G.Y.; Cha, H.J.; Kim, S.; Kim, H.S.; Hwang, H.J.; et al. Glutathione Induced Immune-Stimulatory Activity by Promoting M1-Like Macrophages Polarization via Potential ROS Scavenging Capacity. Antioxidants 2019, 8, 413. [CrossRef] [PubMed]

181. Chang, H.D.; Radbruch, A. The pro- and anti-inflammatory potential of interleukin-12. Ann. N. Y. Acad. Sci. 2007, 1109, 40-46. [CrossRef]

182. Gonzalez-Dominguez, E.; Samaniego, R.; Flores-Sevilla, J.L.; Campos-Campos, S.F.; Gomez-Campos, G.; Salas, A.; Campos-Pena, V.; Corbi, A.L.; Sanchez-Mateos, P.; Sanchez-Torres, C. CD163L1 and CLEC5A discriminate subsets of human resident and inflammatory macrophages in vivo. J. Leukoc. Biol. 2015, 98, 453-466. [CrossRef]

183. Sun, Q.; Fan, T.W.M.; Lane, A.N.; Higashi, R.M. Applications of chromatography-ultra high-resolution MS for stable isotope-resolved metabolomics (SIRM) reconstruction of metabolic networks. TrAC-Trends Anal. Chem. 2020, 123, 115676. [CrossRef]

184. Higashi, R.M.; Fan, T.W.-M.; Lorkiewicz, P.K.; Moseley, H.N.B.; Lane, A.N. Stable Isotope Labeled Tracers for Metabolic Pathway Elucidation by GC-MS and FT-MS. In Mass Spectrometry Methods in Metabolomics; Raftery, D., Ed.; Humana: Louisville, KY, USA, 2014; Volume 1198, pp. 147-167.

185. Moffett, J.R.; Namboodiri, M.A. Tryptophan and the immune response. Immunol. Cell Biol. 2003, 81, $247-265$. [CrossRef] [PubMed]

186. Fan, T.W.; Warmoes, M.O.; Sun, Q.; Song, H.; Turchan-Cholewo, J.; Martin, J.T.; Mahan, A.; Higashi, R.M.; Lane, A.N. Distinctly perturbed metabolic networks underlie differential tumor tissue damages induced by immune modulator beta-glucan in a two-case ex vivo non-small-cell lung cancer study. Cold Spring Harb. Mol. Case Stud. 2016, 2, a000893. [CrossRef]

187. Sellers, K.; Allen, T.D.; Bousamra, M., II; Tan, J.; Mendez-Lucas, A.; Lin, W.; Bah, N.; Chernyayskaya, Y.; MacRae, J.I.; Higashi, R.M.; et al. Metabolic reprogramming and Notch activity distinguish between non-small cell lung cancer subtypes. Br. J. Cancer 2019, 121, 51-64. [CrossRef]

188. Unger, F.T.; Bentz, S.; Krüger, J.; Rosenbrock, C.; Schaller, J.; Pursche, K.; Sprüssel, A.; Juhl, H.; David, K.A. Precision Cut Cancer Tissue Slices in Anti-Cancer Drug Testing. J. Mol. Pathophysiol. 2015, 4, 108-121. [CrossRef]

189. Hell, S.W.; Wichmann, J. Breaking the Diffraction Resolution Limit by Stimulated-Emission-Stimulated-Emission-Depletion Fluorescence Microscopy. Opt. Lett. 1994, 19, 780-782. [CrossRef]

190. Huang, B.; Bates, M.; Zhuang, X. Super-Resolution Fluorescence Microscopy. Annu. Rev. Biochem. 2009, 78, 993-1016. [CrossRef] 
191. Moore, R.P.; Legant, W.R. Improving probes for super-resolution. Nat. Methods 2018, 15, 659-660. [CrossRef] [PubMed]

192. Strack, R. Gentler super-resolution microscopy. Nat. Methods 2018, 15, 764. [CrossRef] [PubMed]

193. Wu, Y.; Shroff, H. Faster, sharper, and deeper: Structured illumination microscopy for biological imaging. Nat. Methods 2018, 15, 1011-1019. [CrossRef] [PubMed]

194. Stringari, C.; Donovan, P.; Gratton, E. Phasor FLIM metabolic mapping of stem cells and cancer cells in live tissues. In Multiphoton Microscopy in the Biomedical Sciences Xii; Periasamy, A., Konig, K., So, P.T.C., Eds.; SPIE: Bellingham, WA, USA, 2012; Volume 8226.

195. Ishikawa-Ankerhold, H.C.; Ankerhold, R.; Drummen, G.P.C. Advanced Fluorescence Microscopy Techniques-FRAP, FLIP, FLAP, FRET and FLIM. Molecules 2012, 17, 4047-4132. [CrossRef] [PubMed]

196. Rose, J.; Martin, C.; MacDonald, T.; Ellis, C. High-resolution intravital NADH fluorescence microscopy allows measurements of tissue bioenergetics in rat ileal mucosa. Microcirculation 2006, 13, 41-47. [CrossRef]

197. Gong, L.; Zheng, W.; Ma, Y.; Huang, Z. Higher-order coherent anti-Stokes Raman scattering microscopy realizes label-free super-resolution vibrational imaging. Nat. Photonics 2020, 14, 115-122. [CrossRef]

198. Szafraniec, E.; Wiercigroch, E.; Czamara, K.; Majzner, K.; Staniszewska-Slezak, E.; Marzec, K.M.; Malek, K.; Kaczor, A.; Baranska, M. Diversity among endothelial cell lines revealed by Raman and Fourier-transform infrared spectroscopic imaging. Analyst 2018, 143, 4323-4334. [CrossRef]

199. Czamara, K.; Majzner, K.; Pacia, M.Z.; Kochan, K.; Kaczor, A.; Baranska, M. Raman spectroscopy of lipids: A review. J. Raman Spectrosc. 2015, 46, 4-20. [CrossRef]

200. Boellner, S.; Becker, K.-F. Reverse Phase Protein Arrays-Quantitative Assessment of Multiple Biomarkers in Biopsies for Clinical Use. Microarrays 2015, 4, 98-114. [CrossRef]

201. de Graaf, R.A.; Brown, P.B.; Mason, G.F.; Rothman, D.L.; Behar, K.L. Detection of 1,6-C-13(2) -glucose metabolism in rat brain by in vivo H-1 C-13 -NMR spectroscopy. Magn. Reson. Med. 2003, 49, 37-46. [CrossRef]

202. Glunde, K.; Bhujwalla, Z.M.; Ronen, S.M. Choline metabolism in malignant transformation. Nat. Rev. Cancer 2011, 11, 835-848. [CrossRef] [PubMed]

203. Boumezbeur, F.; Petersen, K.F.; Cline, G.W.; Mason, G.F.; Behar, K.L.; Shulman, G.I.; Rothman, D.L. The Contribution of Blood Lactate to Brain Energy Metabolism in Humans Measured by Dynamic C-13 Nuclear Magnetic Resonance Spectroscopy. J. Neurosci. 2010, 30, 13983-13991. [CrossRef] [PubMed]

204. de Graaf, R.A.; Rothman, D.L.; Behar, K.L. State of the art direct C-13 and indirect H-1- C-13 NMR spectroscopy in vivo. A practical guide. NMR Biomed. 2011, 24, 958-972. [CrossRef]

205. Cheshkov, S.; Dimitrov, I.E.; Jakkamsetti, V.; Good, L.; Kelly, D.; Rajasekaran, K.; DeBerardinis, R.J.; Pascual, J.M.; Sherry, A.D.; Malloy, C.R. Oxidation of U-C-13 glucose in the human brain at 7T under steady state conditions. Magn. Reson. Med. 2017, 78, 2065-2071. [CrossRef] [PubMed]

206. Marin-Valencia, I.; Ali Hooshyar, M.; Pichumani, K.; Sherry, A.D.; Malloy, C.R. The ratio of acetate-to-glucose oxidation in astrocytes from a single ${ }^{13}$ C NMR spectrum of cerebral cortex. J. Neurochem. 2014, 132, 99-109. [CrossRef] [PubMed]

207. Gadian, D.G. NMR and its applications to living systems, 2nd ed.; Oxford University Press: Oxford, UK, 1995; p. 283.

208. Penet, M.-F.; Bhujwalla, Z.M.; Glunde, K. Magnetic Resonance Spectroscopy in Investigating the Cancer Metabolome in Preclinical Model Systems. In Methodologies for Metabolomics; Lutz, N., Sweedler, J.V., Weevers, R.A., Eds.; Cambridge University Press: Cambridge, UK, 2013; pp. 335-376.

209. Nikolaou, P.; Goodson, B.M.; Chekmenev, E.Y. NMR Hyperpolarization Techniques for Biomedicine. Chem.-Eur. J. 2015, 21, 3156-3166. [CrossRef]

210. Brindle, K.M. Imaging Metabolism with Hyperpolarized C-13-Labeled Cell Substrates. J. Am. Chem. Soc. 2015, 137, 6418-6427. [CrossRef]

211. Ardenkjaer-Larsen, J.H.; Boebinger, G.S.; Comment, A.; Duckett, S.; Edison, A.S.; Engelke, F.; Griesinger, C.; Griffin, R.G.; Hilty, C.; Maeda, H.; et al. Facing and Overcoming Sensitivity Challenges in Biomolecular NMR Spectroscopy. Angew. Chem.-Int. Ed. 2015, 54, 9162-9185. [CrossRef]

212. Lane, D.; Soong, R.; Bermel, W.; Ning, P.; Majumdar, R.D.; Tabatabaei-Anaraki, M.; Heumann, H.; Gundy, M.; Boenisch, H.; Mobarhan, Y.L.; et al. Selective Amino Acid-Only in Vivo NMR: A Powerful Tool to Follow Stress Processes. ACS Omega 2019, 4, 9017-9028. [CrossRef] 
213. Lane, D.; Skinner, T.E.; Gershenzon, N.I.; Bermel, W.; Soong, R.; Majumdar, R.D.; Mobarhan, Y.L.; Schmidt, S.; Heumann, H.; Monette, M.; et al. Assessing the potential of quantitative 2D HSQC NMR in C-13 enriched living organisms. J. Biomol. NMR 2019, 73, 31-42. [CrossRef]

214. Lindeboom, L.; de Graaf, R.A.; Nabuurs, C.I.; van Ewijk, P.A.; Hesselink, M.K.C.; Wildberger, J.E.; Schrauwen, P.; Schrauwen-Hinderling, V.B. Quantum coherence spectroscopy to measure dietary fat retention in the liver. JCI Insight 2016, 1, e84671. [CrossRef] [PubMed]

215. Huber, K.; Khamehgir-Silz, P.; Schramm, T.; Gorshkov, V.; Spengler, B.; Roempp, A. Approaching cellular resolution and reliable identification in mass spectrometry imaging of tryptic peptides. Anal. Bioanal. Chem. 2018, 410, 5825-5837. [CrossRef] [PubMed]

216. Buchberger, A.R.; DeLaney, K.; Johnson, J.; Li, L. Mass Spectrometry Imaging: A Review of Emerging Advancements and Future Insights. Anal. Chem. 2018, 90, 240-265. [CrossRef] [PubMed]

217. Feenstra, A.D.; Duenas, M.E.; Lee, Y.J. Five Micron High Resolution MALDI Mass Spectrometry Imaging with Simple, Interchangeable, Multi-Resolution Optical System. J. Am. Soc. Mass Spectrom. 2017, 28, 434-442. [CrossRef]

218. Roempp, A.; Spengler, B. Mass spectrometry imaging with high resolution in mass and space. Histochem. Cell Biol. 2013, 139, 759-783. [CrossRef]

219. Drake, R.R.; McDowell, C.; West, C.; David, F.; Powers, T.W.; Nowling, T.; Bruner, E.; Mehta, A.S.; Angel, P.M.; Marlow, L.A.; et al. Defining the human kidney N-glycome in normal and cancer tissues using MALDI imaging mass spectrometry. J. Mass Spectrom. 2020, 55. [CrossRef]

220. Angel, P.M.; Bruner, E.; Bethard, J.; Clift, C.L.; Ball, L.; Drake, R.R.; Feghali-Bostwick, C. Extracellular matrix alterations in low-grade lung adenocarcinoma compared with normal lung tissue by imaging mass spectrometry. J. Mass Spectrom. 2020, 55, e4450. [CrossRef]

221. Fan, T.W.-M.; Lane, A.N.; Higashi, R.M. Stable Isotope Resolved Metabolomics Studies in ex vivo Tissue Slices. Bio-Protocol 2016, 6, e1730. [CrossRef] [PubMed]

222. Fan, T.W.-M.; Lorkiewicz, P.; Sellers, K.; Moseley, H.N.B.; Higashi, R.M.; Lane, A.N. Stable isotope-resolved metabolomics and applications to drug development. Pharmacol. Ther. 2012, 133, 366-391. [CrossRef]

223. Fan, T.W.-M. Sample Preparation for Metabolomics Investigation. In The Handbook of Metabolomics: Pathway and Flux Analysis, Methods in Pharmacology and Toxicology; Fan, T.W.-M., Lane, A.N., Higashi, R.M., Eds.; Springer Science: New York, NY, USA, 2012; Volume 17, pp. 7-27.

224. Mattingly, S.J.; Xu, T.; Nantz, M.H.; Higashi, R.M.; Fan, T.W.M. A carbonyl capture approach for profiling oxidized metabolites in cell extracts. Metabolomics 2012, 8, 989-996. [CrossRef]

225. Lane, A.N.; Tan, J.; Wang, Y.; Yan, J.; Higashi, R.M.; Fan, T.W.-M. Probing the metabolic phenotype of breast cancer cells by multiple tracer Stable Isotope Resolved Metabolomics. Metab. Eng. 2017, 43, 125-136. [CrossRef] [PubMed]

226. Lane, A.N.; Yan, J.; Fan, T.W.-M. 13C Tracer Studies of Metabolism in Mouse Tumor Xenografts. Bio-Protocol 2015, 5, e1650. [CrossRef] [PubMed]

227. Lane, A.N.; Fan, T.W.-M. NMR-based Stable Isotope Resolved Metabolomics in systems biochemistry. Arch. Biochem. Biophys. 2017, 628, 123-131. [CrossRef] [PubMed]

228. Le, A.; Lane, A.N.; Hamaker, M.; Bose, S.; Barbi, J.; Tsukamoto, T.; Rojas, C.J.; Slusher, B.S.; Zhang, H.; Zimmerman, L.J.; et al. Myc induction of hypoxic glutamine metabolism and a glucose-independent TCA cycle in human B lymphocytes. Cell Metab. 2012, 15, 110-121. [CrossRef] [PubMed]

(C) 2020 by the authors. Licensee MDPI, Basel, Switzerland. This article is an open access article distributed under the terms and conditions of the Creative Commons Attribution (CC BY) license (http://creativecommons.org/licenses/by/4.0/). 